Center for

Ouantitative

Economics

\title{
Effects of Bilateralism and the MFN Clause on International Trade - Evidence for the Cobden-Chevalier Network, (1860-1875)
}

Markus Lampe $^{\dagger}$

$2 / 2009$

${ }^{\dagger}$ Department of Economics, University of Münster, Germany and Department of Economics, University of Copenhagen, Denmark 


\title{
Effects of Bilateralism and the MFN Clause on International Trade - Evidence for the Cobden-Chevalier Network, (1860-1875)
}

\author{
Markus Lampe \\ Institut für Wirtschafts- und Sozialgeschichte \\ Westfälische Wilhelms-Universität Münster \\ Domplatz 20-22 \\ D-48143 Münster \\ mlampe@uni-muenster.de
}

and

Department of Economics

University of Copenhagen

markus.lampe@econ.ku.dk

JEL: N73, F13

KEYWORDS: preferential trade agreements, Anglo-French treaty, bilateralism, liberalisation, gravity model

\section{ACKNOWLEDGEMENTS:}

This paper is part of the research project "Causes and effects of international trade regimes: the Cobden-Chevalier network, c.1860-77”, funded by Fritz Thyssen Stiftung. During the research, substantial advice was provided by the Carsten Burhop, Camilla Josephson, Thorsten Lübbers, Ulrich Pfister, Paul Sharp, Martin Uebele, and participants of the Economic History Society's Annual Conference 2007, the $2^{\text {nd }}$ Sound Economic History Workshop, and seminars at the Universities of Münster and Copenhagen. I would like to thank Hendrik Buhrs, Christian Flick, Elena Heßelmann, Sonja Lohmann, Annabell Maßß, and Hendrik Voss for substantial assistance in collecting the underlying data.

The published version of this article is available in the The Journal of Economic History, Vol. 69, No. 4 (December 2009) (C) The Economic History Association. It is available online on the JOURNAL's homepage at http://journals.cambridge.org/action/displayJournal?jid=jeh. 


\title{
Effects of Bilateralism and the MFN Clause on International Trade - \\ Evidence for the Cobden-Chevalier Network, (1860-1875)
}

\begin{abstract}
This study contributes to a revised picture of nineteenth-century bilateralism. Employing a new disaggregated dataset, it argues that bilateral treaties did not implement general free trade, but instead reduced tariffs unevenly through commodity-specific preferences, especially favoring manufactured goods. Gravity model estimates show that specific liberalizations translated into systematic increases in exports of corresponding items, but not overall trade. Exporters of countries whose governments used bilateralism strategically to bring down partner tariffs benefitted most. Hence, the network in form and outcome is more properly identified with reciprocal liberalization practiced by the French than with British free trade ideology.
\end{abstract}


The Anglo-French Treaty of Commerce of 1860 and the more than 50 bilateral preferential trade agreements that followed it are widely credited with having brought "free trade" to the European continent. The initial treaty takes its name from those of British negotiator and statesman Richard Cobden, who is even more famous as a leader of the British Anti-Corn Law movement, and French free-trade economist politician Michel Chevalier. ${ }^{1}$ The entire network that evolved after 1860 has been identified with the free trade doctrine. Under denominations such as "European free trade era" and "the First Common Market" it attracted the attention of scholars not only in economic history, but also in international economics and international relations. ${ }^{2}$

Until very recently, little systematic investigation has been pursued as to whether the network of bilateral treaties achieved its central aim: raising international trade flows. Inspired by the questioning of actual trade enhancing effects of the GATT-WTO liberalizations by Andrew K. Rose Olivier Accominotti and Marc Flandreau, undertook an assessment of the Cobden-Chevalier Network employing gravity models. They conclude that the network "did not give any boost to international trade whose expansion actually started losing momentum after $1860^{\prime \prime}$, and that bilateralism was as ineffective in promoting trade as multilateralism is in the present day, according to most of Rose's empirical results. Taking these results together, the use of commercial diplomacy for liberalizing world trade seems highly questionable.

However, it is even more questionable whether commercial diplomacy aims at liberalizing world trade. The present article contributes to an enhanced understanding of the CobdenChevalier Network in the sense that, despite propaganda for free trade and world peace by Cobden and the Cobdenites, ${ }^{4}$ identifying the bilateral treaties with the free trade doctrine is a mistake: If one reads the treaties beyond the preambles and examines the actual stipulations, it becomes evident that liberalizing overall trade can hardly be seen as their foremost goal. Preferences were negotiated item by item, and the result was far from linear across all commodities. Tariff cuts and remaining tariffs reflected negotiating parties' preferences, and as such were more frequent and more pronounced for manufactures and high-tariff "luxury goods" than for raw materials. As a consequence, investigating the treaties' impact on total

1 Chevalier played an important part in the preparation of the agreement although he was not an official French representative. See Dunham, Anglo-French Treaty, chs. 3-5.

2 Important contributions to our understanding of nineteenth-century bilateralism include Pahre, Politics; Accominotti and Flandreau, "Bilateral Trade Treaties"; and Irwin, "Multilateral and Bilateral Trade Policies." Textbook accounts are to be found in, inter alia, Brawley, Power, ch. 11; and Bairoch, "European Trade Policy," pp. 36-51. Influential studies from in the international relations field include Stein, "Hegemon's Dilemma"; and Lazer, "Free Trade Epidemic."

3 Accominotti and Flandreau, "Bilateral Trade Treaties" (quote from p. 175); Rose, "Do We Really Know?"

4 See Howe, Free Trade, pp. 92-93, 105-10; and Wendt, "Freihandel." 
trade is not entirely appropriate. Hence, I use a new disaggregated dataset to estimate gravity models at the commodity-group level. The results show that while the network offered systematically positive effects for many commodity groups, but their sum is too small to show up as statistically significant in the aggregate. Especially, trade in manufactures and luxury goods rose. Exporters from countries whose diplomats were meticulous in negotiating tariff reductions tailored to domestic export interests reaped notably higher benefits. This suggests that commercial diplomacy did make a difference, albeit not necessarily in promoting universal free trade.

\section{COMMERCIAL POLICY AND THE DEVELOPMENT OF FOREIGN TRADE AFTER 1860}

Since the end of the Napoleonic Wars, and especially in the 1840s and 1850s, Great Britain and the economies of Continental Europe underwent a process of increasing internal and external physical market integration. ${ }^{5}$ Advances in transport and communication technology had reduced natural barriers to trade, while the suppression of internal tariffs, most prominently in Germany, reduced institutional barriers to trade. ${ }^{6}$ Progressing industrialization, economic growth and internal integration had caused national producers to become more and more dependent on foreign supplies of raw materials and - in the most advanced branches - on foreign markets to sell their commodities. Concurrently, European market integration had been brought to the forefront for many commodities in the 1840s and especially in the 1850 s due to integration in transport and communication, as well as unilateral tariff reforms. As a consequence, at the end of the $1850 \mathrm{~s}$, tariff levels were generally low for foodstuffs and many raw materials for industrial production; while in most Continental European countries, tariffs on manufactured products such as iron and steel, and textiles remained high to protect national industries from inflows of cheap British products. ${ }^{7}$ The United Kingdom itself constituted an exception, as tariffs had been brought down for almost all goods except "luxury articles" such as tobacco, coffee, wines, spirits, fancy goods (silk wares, etc.), and sugar, whose duties made up an important share in total public revenue.

To gain an internationally comparable picture of the distribution in tariff rates across countries and commodities, Table 1 displays ad valorem tariff equivalents for major noncolonial commodity groups in international trade in 1859 , just prior to the conclusion of

\footnotetext{
5 Jacks, "Intra- and International Commodity Market Integration"; Shiue, "From Political Fragmentation"; Kaukiainen, "Shrinking the World"; and Ejrnæs and Persson, "Market Integration."

6 Bairoch, "European Trade Policy," pp. 15-17; and Keller and Shiue, "Tariffs."

7 Bairoch, "European Trade Policy," pp. 28-37.
} 
the Cobden-Chevalier Treaty. I employ a new dataset that provides information on trade flows, tariff rates and commercial treaties stipulations for the United Kingdom, the United States, France, Belgium, the Netherlands, Austria-Hungary and the German Zollverein from 1857 to 1875 in 21 internationally comparable commodity groups. ${ }^{8}$ As the period under study predates even the beginning of the unification of tariff and statistical classifications by four decades, and national classifications were elaborated according to national industry and protection structures along with prevailing political beliefs, this partial classification was constructed from national trade statistics of the aforementioned countries in the following way: I first determined the 50 items with the highest import and export values for every country in 1865 . After exclusion of articles that were important in one country only or which did not fit the research design, a partial classification of 21 internationally comparable commodity groups was established that forms the basis of all subsequent research. It should be noted that due to the aforementioned restrictions, the dataset explicitly excludes colonial and tropical commodities (cotton, tobacco, guano, indigo, or cane sugar) that were not produced to a considerable extent in Europe, and minerals like copper, zinc, or tin, whose exportability depended on the availability of deposits.

[Table 1 about here]

Table 1 shows that while average tariffs were already fairly low in most of Europe at the end of the 1850s, actual rates varied considerably across countries and industries, reflecting national industry structures and government preferences in protection and revenue generation. While tariffs on wheat ranged from 0.0 to 2.5 percent, especially textiles, and iron and steel products were taxed very unevenly, with duties ranging from 0.0 percent in Britain to levels well beyond 20 percent in France, the Zollverein, and Belgium.

Peter T. Marsh highlighted this unequal distribution of tariffs, prior to 1860 , as the watershed for the spread of the commercial negotiations, ${ }^{9}$ alongside the variety of political developments and diplomatic events in the "concert of powers" in Europe. ${ }^{10}$ Marsh stresses the importance of exporters as lobbies for tariff reductions in their export destinations, especially the woolens and worsteds manufacturers of the West Riding of Yorkshire on the British side. For French negotiators, the high British tariffs on wines and spirits were the central target, and vintners of the Gironde as well as producers of fine silken articles were the main interest groups favorable to a treaty that otherwise was harshly opposed by French

\footnotetext{
8 The dataset is documented in detail in Lampe, "Bilateral Trade Flows."

9 Marsh, Bargaining on Europe, chs. 3-4.

10 Dunham, Anglo-French Treaty; Iliasu, "Cobden-Chevalier Commercial Treaty”, and Wendt, "Freihandel."
} 
manufacturers. ${ }^{11}$ Consequently, the Cobden-Chevalier Treaty led to a reduction of British duties on lighter wines by about 80 percent and the abolition of remaining British duties on articles of silk and different sorts of woolens such as laces, shawls, and coverlids. France abolished import prohibitions for British manufactures, and French duties for British semimanufactures were brought down to levels around 10 percent, while manufactures would pay ad valorem equivalents of about 15 percent. Both parties thus achieved tailor-made liberalizations for their exports that would not have been implemented unilaterally by the other party. The results of the Cobden-Chevalier Treaty came closer to "moderate protection" than to "free trade," as substantial duties remained. ${ }^{12}$

Marsh also establishes why the subsequent development had to occur via France and why specific interests mattered for the treaty network's expansion at least as much as they had in the negotiations of the original treaty. Because it unilaterally generalized the "concessions" of the treaty of 1860 , the United Kingdom had few potentially attractive preferences left for further negotiations. Official British diplomacy stuck to the free trade doctrine. ${ }^{13}$ In the terminology of Jagdish Bhagwati, it argued for full reciprocity (absolutely identical market access aiming at nondiscriminatory free trade) while continental parties acted on the assumption of first-difference reciprocity (equal concessions made departing from differing initial conditions). ${ }^{14}$ Thus it was that Great Britain, in further treaties, obtained mainly pure most favored nation (MFN) agreements, while the refusal to generalize its preferences granted enabled France to offer her differential treatment to further trading partners in subsequent negotiations. For example, Belgium and Prussia wanted to achieve similar conditions and further liberalizations tailored to their own export industries. The results of French negotiations with both saw further reductions in tariffs and increasing discrimination faced by outsiders to this emerging network. The latter aspect created incentives for further negotiations and the expansion of the network, while the former advanced trade liberalization. ${ }^{15}$ The result was that by the early 1870 s, a densely knotted network of more than 50 bilateral treaties had formed in Europe which lowered average tariffs to a degree unmatched in international trade until the 1980s.

Although all agreements were formally bilateral, the resulting network possessed multilateral characteristics. All treaties stipulated the repeal of import and export prohibitions; freedom of transit; measures fostering the freedom of transnational commerce; and mutual

\footnotetext{
11 Nye, "Myth"; Nye, War; Irwin, "Free Trade"; and Dunham, Anglo-French Treaty.

${ }^{12}$ Irwin, "Multilateral and Bilateral Trade Policies," p. 96; Nye, "Changing French Trade Conditions"; and Stein, "Hegemon's Dilemma."

13 Marsh, Bargaining on Europe, ch. 3; Howe, Free Trade, chs. 3-4.

14 Bhagwati, "Introduction."

15 Lazer, "Free Trade Epidemic."
} 
concession of unconditional MFN status. Not all treaties included specific liberalizations; an increasing proportion of the agreements concluded in the late 1860 s and 1870 s convened pure mutual MFN status only. Still, these later treaties constituted an important prerequisite for the network as a stable system, as they linked stipulations of preceding treaties. ${ }^{16}$ As an institution, the Cobden-Chevalier Network might be looked upon as similar to modern-day free trade areas, but with residual elements of internal discrimination.

[Table 2 about here]

Table 2 gives a picture of the distribution of preferences and liberalizations across commodity groups in the treaties. It has been elaborated from a total of 55 bilateral MFN treaties ratified among European countries until 1875. Of these agreements, 22 contained tailor-made preferences, while 33 convened MFN-status only. ${ }^{17}$ Tailor-made preferences are defined as explicit, new tariff reductions convened between the actual parties of a bilateral treaty, while the term $M F N$ liberalizations refers to the sum of tailor-made preferences and liberalizations transmitted via MFN from former treaties or obtained ex post by transmission of further liberalizations from partners' subsequent negotiations with other parts.

The table shows that the main focus of the bilateral treaties was on reducing tariffs on manufactured articles, such as textiles (cloths rather than yarns), ironware, articles of leather and rubber, and especially on wines and stronger alcoholic beverages. Negotiators certainly were not overly interested in cereals and milling products, which were some of the most important articles in international trade of that age and are most prominent in modern-day investigation of nineteenth-century commodity market integration. ${ }^{18}$ Of course, a glance at Table 1 reveals little to negotiate over for these commodities. This suggests that we should be cautious in interpreting overall effects, as a large segment of international trade was virtually excluded or at least underrepresented in the treaties.

[Table 3 about here]

Table 3 shows the outcome of commercial policy in the 1860 s and early 1870 s, as reflected in the state of tariffs in 1875. In comparison with Table 1, it can be summarized as follows: While tariffs on many items were substantially reduced, others remained almost unaltered. British wine and spirits tariffs were reduced to less than one-third of their 1859

16 Irwin, "Multilateral and Bilateral Trade Policies," pp. 96-101.

17 See App. 1 for a cross-table of sealing dates

18 Wheat, rye, and milling products represented about 5.6 percent of all imports of the countries in Table 1, and 13.2 percent of total imports in the commodity groups of Table 1. 
amount, as were French tariffs on many items, as well as the Zollverein's tariffs on cottons, iron and steel of all kinds, Belgian tariffs on woolen yarn, Austria-Hungary's tariffs on grains, yarns, and cloth, and, unilaterally, Dutch tariffs on yarns of all kinds. Raw materials remained mainly unaffected with a few exceptions, for example, the suppression of the British duties on timber as a result of the prolonged Anglo-Austrian negotiations. ${ }^{19}$ Table 3 confirms the unequal distribution of actual liberalization across commodity groups and countries, and it illustrates the general advance in liberalizing foreign trade: Average tariff levels for manufactured goods in Continental Europe dropped markedly, while they increased to unprecedented levels in post-Civil War United States. ${ }^{20}$

However, only actual trade flows can reveal whether foreign trade increased effectively. Contemporary accounts relied mainly on the comparison of ex ante and ex post trade volumes. As an example, British expert opinion published in early 1869, in The Economist, on the effects of the Cobden-Chevalier Treaty stated that British imports from France had at least doubled in the first eight years after its ratification, while exports and re-exports to France had increased even more. ${ }^{21}$ It explains that these increases could not be sufficiently attributed to augmented general prosperity, and that

"[t]he significance of the augmentation should appear yet more in details. The special advantage of the treaty was intended to be the multiplication of exchanges in the articles which only one country produced, or in producing which it had an advance. [...] Thus the value of our import of wine has nearly trebled in the eight years, while the quantity we take is from four to six times higher than it was. The progression in this article is consequently far above the general progress of our imports from France, which is so far a sign that the general augmentation is due to the augmentation in articles encouraged by the treaty."22

The article demonstrates that the increase in imports of silk wares from France had been even higher than in wines. British exports to France in coal and textiles, most notably woolens and worsteds, had also grown well above average. Leone Levi confirmed these observations for later years, and gave additional figures regarding the exports of Austria-

19 Helleiner, Free Trade, pp. 78-79. The reduction of British wheat duties to zero was not due to commercial treaties; they were unilaterally abolished in 1869; see "Großbritannien. Zollfreie Einfuhr von Getreide, Mehl und ähnlichen Artikeln (General Order vom 31. Mai 1869)," Preußisches Handelsarchiv (1869, part 2) p. 50. French wine duties were increased in 1869 and 1871, but only for non-MFN countries; see "Frankreich. Modifikation der Eingangsabgabe für Weine (Annales du commerce extérieur Nr. 1813),” ibid. (1869, part 2), p. 305; and "Frankreich. Gesetz, betreffend die Abgaben von Wein, Obstweinen, Meth, Alkohol, Spirituosen, Bier, Spielkarten und Zucker (Journal official No. 245),” ibid. (1871, part 2), p. 324.

20 See also Bairoch, “European Trade Policy,” p. 42.

21 "The Effects of the French Treaty on the Course of Trade," The Economist (13 February 1869), pp. 173-175.

22 Ibid. 
Hungary, Belgium, France, the Netherlands, Italy and the United Kingdom. ${ }^{23}$ Since then, similar figures and arguments have been published and cited by contemporaries and historians alike. ${ }^{24}$

Recently, Accominotti and Flandreau took a more systematic approach and estimated various versions of the gravity model for bilateral trade totals between 1850 and 1880 . The result is a consistent lack of statistically significant effects of the bilateral agreements on overall trade flows between their parties. ${ }^{25}$ Hence, bilateralism appears to be a useless device, if an increase of international trade is the aim.

However, the material presented above makes clear that the treaties did not pursue overall trade liberalization, but the reduction of duties for specific commodities, and thus were intended to create economic possibilities for certain domestic exporters. In contrast, certain critical elements of international trade were hardly mentioned. Therefore, to examine the effects of the treaties in an appropriate manner, my subsequent analysis focuses on trade flows in specific commodity groups, which are those identified as being of considerable weight in the exports of those countries in Western and Central Europe, whose governments created the treaty network.

\section{COMMERCIAL TREATIES AND BILATERAL TRADE, 1857-1875: DATA AND METHODS}

To assess the incidence of specific preferences and liberalizations, I gathered bilateral trade data from contemporary trade statistics for the each of the commodity groups presented in the previous section. Because only a few countries published systematic and reliable disaggregated statistics, the sample had to be limited to seven key countries in the world trade of our period: the United Kingdom, the United States, France, Belgium, the Netherlands, Austria-Hungary and the German Zollverein/Kaiserreich. Among these countries were also the core countries of the Cobden-Chevalier Network. The dataset contains import values for all of them at ten points in time, namely, every second year between 1857 and 1875 . The core sample contains the 42 country-pairs constituted by these seven countries. An extended version, which is used for robustness checks of the results, also includes imports of these

\footnotetext{
23 Levi, "Statistical Results."

24 Marsh, Bargaining on Europe, ch. 4; Dunham, Anglo-French Treaty, chs. 9-14; Cadier, "Consequences."

25 Accominotti and Flandreau, "Bilateral Trade Treaties"; see also the regression results by López-Córdova and Meissner, "Exchange Rate Regimes."
} 
countries from Switzerland, Italy, Spain, Portugal, Denmark, Sweden-Norway, and Russia. ${ }^{26}$

The dataset is presented and examined in detail in a separate study. ${ }^{27}$ Its salient features include: First, the use of disaggregated data that enabled dealing comprehensively with inadequate official prices and lack of valuation. These were most notorious in the Zollverein's foreign trade statistics, which provided physical quantities only, and in Dutch statistics, in which unaltered benchmark prices established in 1846 were used for many items until 1914. In these instances, values were calculated and corrected using corresponding prices from reliable sources, in this case, the foreign trade tables published for the port of Hamburg, the United Kingdom and France. Second, the dataset prepared for this study is the first that comprehensively accounts for incorrect assignment of partner countries. This problem results from trade in transit and via entrepôts that generally was not recorded for the country it was originally shipped from, but rather the country whence it physically entered (that is, the country of last land border crossed and the last port visited by an incoming ship). ${ }^{28}$ As trade in transit represented more than 25 percent of all trade flows of the countries in the sample, uncorrected bilateral data are distorted to a considerable extent. I performed a comprehensive correction using partner countries' transit statistics to separate actual domestic bilateral exports of immediate partners from transit that just passed through the country from where it physically arrived at its final destination. Furthermore, in view of measuring retained imports for home consumption only, I removed disguised transit and entrepôt trade volumes, that is, trade reported for merchandise that was imported with the sole purpose of being reexported. $^{29}$

To analyze systematically the relation between trade agreements and trade flows between the participating countries, I employed the standard method in this field, the gravity model. For aggregate trade flows, it is used in its basic specification, and thus results are comparable to those obtained by Accominotti and Flandreau, and Rose. ${ }^{30}$ The gravity model relates

26 Before 1861, for "Italy" the sum of data for Sardinia, Two Sicilies, Tuscany, and the Papal States were used. Three country-pairs have not been included in the dataset due to border issues that could not be resolved: imports of the Zollverein and Austria-Hungary from Denmark and imports of Austria-Hungary from Switzerland.

27 Lampe, "Bilateral Trade Flows."

28 A prominent example is British pig and bar iron exported to Germany via the Netherlands or Belgium.

29 The practice of disguised transit avoided complications and costs associated with bureaucratic transit and bond procedures. It was most attractive for duty-free goods. Because the merchandise was declared as imported for the home-market twice (in the country "disguisedly transited" and at its final destination after re-export) it is double-counted in official trade statistics if not removed. Its presence was most notable in the statistics of Belgium and the Netherlands; see ibid.; Horlings, "International Trade"; and Lindblad and van Zanden, "Buitenlandse handel."

30 Accominotti and Flandreau, "Bilateral Trade Treaties"; and Rose, "Do We Really Know?" 
bilateral imports by countries $i$ from trade partners $j$ in period $t\left(I M_{i j t}\right)$ to the national incomes of importer $\left(Y_{i}\right)$ and exporter $\left(Y_{j}\right)$, and the economic distance that separates them. Economic distance is proxied by geographic distance $\left(D_{i j}\right)$ in kilometers. Per capita incomes $\left(Y_{i} /\right.$ Pop $\left._{i}\right)$ of importers and exporters are included to model demand behavior. ${ }^{31}$ Hence, the formulation for aggregate trade is:

$$
\ln \left(\mathrm{IM}_{\mathrm{ijt}}\right)=\beta_{0}+\beta_{1} \ln \left(\mathrm{Y}_{\mathrm{i}} \mathrm{Y}_{\mathrm{j}}\right)_{\mathrm{t}}+\beta_{2} \ln \left(\mathrm{Y}_{\mathrm{i}} / \mathrm{Pop}_{\mathrm{i}}{ }^{*} \mathrm{Y}_{\mathrm{j}} / \mathrm{Pop}_{\mathrm{j}}\right)_{\mathrm{t}}+\beta_{3} \ln \left(\mathrm{D}_{\mathrm{ij}}\right)+\Sigma \beta_{\mathrm{m}} \Sigma \ln \left(\mathrm{Z}_{\mathrm{ijm}}\right)_{\mathrm{t}}+\varepsilon_{\mathrm{ijt}}
$$

Dummies for common borders, common language, the American Civil War (1860-1865) and wars on the European continent are included as in the vector of additional control variables, $\Sigma \beta_{m} \Sigma \ln \left(Z_{i j m}\right)_{t}{ }^{32}$ Common borders and common languages are expected to influence trade positively due to direct trade routes and easier communication; these variables thus refine the concept of economic distance. Wars are expected to disrupt trade flows. ${ }^{33}$ In addition to the aforementioned control variables, the estimated model includes a timeinvariant dummy variable for each country as an importer and time-specific dummy variables for each period. ${ }^{34}$

The specification of the gravity model is modified for the disaggregated research design, because some of the explanatory variables employed at the aggregate level do not necessarily explain trade in individual commodity-groups, due to differing national production structures. In the commodity-level estimates, elements of bilateral import functions and the original

31 Income per capita is not a theoretically required part of the gravity equation, and has been introduced mainly for comparison in the same way as in Rose, "Do We Really Know?"; and Accominotti and Flandreau, "Bilateral Trade Treaties." Its omission does not have any qualitative impact on the estimates, except that the coefficient for Cobden becomes insignificant in the PPML core estimate.

32 Popular variables that were omitted because they would have identified only one country or country-pairs already otherwise covered are island status, landlocked, colonial ties, and the Latin Monetary Union.

33 The Civil War variable was coded as "1" for the United States as an importer or exporter from 1861 to 1865 , inclusive. The European war variable was coded for the Second Italian War of Independence (1859) and the Franco-Prussian War (1870/71), and has a value of " 1 " if in a country-pair, one country is at war, or if major trade flows between two countries transit a country at war.

34 To account for border changes, effects for Austria-Hungary, France, Germany and Italy have been split up. Country-specific dummy variables are included following the concept of "multilateral resistance"; see Anderson and van Wincoop, "Gravity"; and Baldwin and Taglioni, "Gravity." Baldwin and Taglioni demonstrate that one should correctly use time-varying fixed effects. However, in our case, this would involve the introduction of 140 additional dummies in estimation with 420 observations, leading to an unacceptable decrease in degrees of freedom. Exploratory tests with country-fixed effects for periods of four to six years demonstrated that significance and sign of the results presented here remain unchanged for OLS estimates. For PPML estimates (see below), the infeasibility of this approach for the present dataset was proven, as the suest correction proved impossible. As to the size of the effects, the presented estimates here should be seen as upper-bounds. 
gravity approach are combined in the following way: Importers' national income $\left(Y_{i}\right)$ is maintained as a right-hand side variable, as it is the best available demand measure in our period. $^{35}$ In contrast, exporters' national income is dropped, because the assumption of uniform production and export structures across commodity groups for all countries is implausible. To account for internationally differing production capacities in each commodity-group, proxies for comparative advantage and specific factor endowments would be proper measures, but unfortunately they are not available for the period under study to a satisfactory extent. Hence, they were proxied by time-invariant exporter dummies, assuming that the international distribution of production did not change substantially.

Distance $\left(D_{i j}\right)$ as a proxy for bilateral transport costs is maintained in the estimates, as are the dummies for common language, borders, wars, and importer- and period-specific fixed effects contained in $\Sigma \beta_{\mathrm{m}} \Sigma \ln \left(\mathrm{Z}_{\mathrm{ijm}}\right)_{\mathrm{t}}$. Thus, the commodity-specific equation is:

$$
\ln \left(\mathrm{IM}_{\mathrm{ijt}}\right)=\beta_{0}+\beta_{1} \ln \left(\mathrm{Y}_{\mathrm{i}}\right)_{\mathrm{t}}+\beta_{2} \ln \left(\mathrm{D}_{\mathrm{ij}}\right)+\Sigma \beta_{\mathrm{m}} \Sigma \ln \left(\mathrm{Z}_{\mathrm{ijm}}\right)_{\mathrm{t}}+\varepsilon_{\mathrm{ijt}}
$$

To assess the effects of the treaties, three kinds of dummy variables have been coded from the treaty texts: a) a variable called Cobden that captures the presence of a treaty in general (the variable used by Accominotti and Flandreau); b) a variable called $M F N$ that codes all commodity-specific liberalizations granted or transmitted under the MFN clause; and c) tailor-made preferences (Tailor), that is, new preferences that reduced the lowest tariff level established in former treaties. Statistically significant and positive coefficients for these variables will be interpreted as a systematically positive impact of the corresponding bilateral agreements on their parties' bilateral trade flows. Tailor-made preferences were only coded for the first bilateral treaty that contained them; if they were granted by the same country in later treaties, these repetitions were coded as $M F N$ only. Tailor-made preferences, in general, must need to have benefited directly the export industries of the partner country concerned, while their transmission through the MFN clause may have produced rather indiscriminate effects. ${ }^{36}$ Nevertheless, because tailor-made preferences in many cases were very specific, their impact on trade in the respective category might not be traceable by commodity group-

35 Humphrey, "Disaggregated Import Functions", Konno and Fukushige, "Bilateral Import Demand Functions." The simultaneous inclusion of national incomes $\mathrm{Y}_{\mathrm{i}}$ and $\mathrm{Y}_{\mathrm{i}} / \mathrm{Pop}_{\mathrm{i}}$ led to inappropriate estimates. As a consequence, per capita incomes were dropped, because they are not theoretically required.

36 For example, in its treaty with Portugal of 1866, France agreed to limit its duties on wine to 0.30 Francs per hectoliter (then the actual general-tariff rate). Via MFN the United Kingdom, Sweden, Norway, Belgium, and the Netherlands, among others, also "benefitted" formally, despite lacking significant wine producers. Parry, ed., Consolidated Treaty Series, vol. 132, pp. 413-37. 
specific dummy-variables. ${ }^{37}$ Figure 1 shows the evolution of Cobden, MFN, and Tailor for both the core and extended sample over time.

[Figure 1 about here]

In the basic equation for aggregate trade, the treaties can only be introduced through the dummy variable Cobden. By contrast, at the commodity-group level Cobden, and Tailor can be differentiated and are included in separately estimated models. As the previous section has shown that specific liberalizations were central to the network, I expect to find a clearer picture for Tailor and $M F N$ than for Cobden, because the latter is only a very rough proxy at the disaggregated level. It is coded as " 1 " for all commodity groups, if a bilateral treaty exists, although not all commodity groups were necessarily covered by that treaty.

The model is later refined to assess the evolution of treaty effects and to link specific liberalizations to the development of exports at the national level as described below.

Technically, I estimate equation (2) individually for each of the 21 commodity groups with Ordinary Least Squares (OLS) and Poisson Pseudo-Maximum Likelihood (PPML) alternatively. ${ }^{38}$ The commodity-group specific estimates are then converted into a system of seemingly unrelated regressions to correct for cross-equation error correlations due to identical conditions in the time dimension. ${ }^{39}$

All estimates were made using unidirectional trade flows (imports) and data in nominal current prices converted to $£$ Sterling at annual average nominal exchange rates. ${ }^{40}$ National incomes in current prices were obtained and extrapolated from different sources reported in Appendix 2.

37 For example, the British and Austrian negotiators bargained in 1869 about whether certain velvets and velvet-like woven wares of cotton and wool were to be transferred from the class of open-woven (high-tariff) wares to plain, closely-woven (lower-tariff) wares, only to find out that the question had been settled between Austria-Hungary and the Zollverein in a former MFN treaty in 1868;Helleiner, Free Trade, pp. 123-28.

38 Santos Silva and Tenreyro, "Log," have shown that LS estimates of log-linear models (like equations 1 and 2) are likely inefficient, biased, and/or even inconsistent. They proposed PPML with robust standard errors as a superior alternative. Additionally, PPML allows for including " 0 " observations in the dependent variable, which have to be excluded or treated improperly under log-linear OLS estimates.

39 See also Subramanian and Wei, "WTO." This is done using suest, a nonstandard application of the sandwich estimator implemented in STATA. It calculates robust standard errors that also account for clustering by county-pairs (Weesie, "sg121"). Additionally, it allows estimating consistent cross-equation "average effects" (constrained coefficients) for specific variables using Wald tests.

40 Baldwin and Taglioni, "Gravity.” Exchange rates are from Schneider, Schwarzer and Zellfelder, Währungen; and Denzel, Währungen. Data was rounded to thousands of pounds because of different degrees of detailedness of national statistics; for OLS estimates, values below $£ 1,000$ are set to zero. 


\section{RESULTS}

[Table 4 about here]

Table 4 shows the results for the estimation of equation (1) for aggregate bilateral trade, that is, the sum of trade in all commodity groups. They are in line with theoretical expectations for gravity model estimates and replicate the results of Accominotti and Flandreau $^{41}$ : Larger common market size corresponds to higher trade volumes and higher distance goes along with less trade. The coefficients for common language are also always positive and significant, while the border coefficient is positive in all specifications, but not always significant at the 5 percent level. The coefficient for income per capita is significantly positive for the core sample, but insignificant for the extended sample. Wars seem to have had an overall negligible impact on trade flows. ${ }^{42}$ Most important, the coefficient of the Cobden variable is slightly positive, but statistically insignificant. ${ }^{43}$

\section{[Tables 5 and 6 about here]}

However, our main focus lies in the disaggregated level, because liberalizations were commodity-specific. Table 5 reports the key results of the system of commodity-group specific estimates of equation (2) for the core sample. As the full results involve a large amount of parameters (21 equations with 43 variables each), only the commodity-specific coefficients for the treaty dummies are displayed. The first column contains the estimates for Cobden, the second for MFN liberalizations, and the third for tailor-made preferences. Table 6 reports the values of the constrained (average) coefficients for the key variables across all commodity groups. They were obtained from the results underlying Table 5, using Wald tests for equality of coefficients. The constrained coefficients are rightly signed and significantly different from zero. The coefficient for Cobden is in the same range as in Table 4, but now significantly positive for the favored PPML-SUR estimate. In addition, we now see that

\footnotetext{
41 Accominotti and Flandreau, "Bilateral Trade Treaties," Tables 4 and 5.

42 This might be attributed to the fact that US exports of, for example, cotton and tobacco, are not included in the dataset. Wars in Europe were rather short and did not systematically disrupt overall trade flows.

43 Ibid. See note 31 on a simple robustness check for the Cobden coefficient in PPML core: The exclusion of income per capita leads to an insignificant estimate.
} 
commodity-specific preferences had a traceable impact on trade flows: The constrained coefficients for MFN and Tailor are statistically significant and positive in their respective models. Furthermore, in the disaggregated estimations, the average effect of wars both in the United States and in Europe is now estimated as significantly negative by PPML. This confirms that the disaggregated estimates do not only contain more information, but also allow more precise point estimates. The Pseudo- $\mathrm{R}^{2}$ is 0.90 for the system, ranging from 0.81 (for silk) to 0.97 (for linens and wine) in the commodity-group equations.

Nevertheless, the p-values from corresponding Wald-test $\chi^{2}$-statistics for equality of coefficients in Table 6 make clear that the constrained coefficients themselves do not represent identical coefficients across equations. Therefore, the results for commodityspecific equations deserve attention. For the demand variable $Y_{i}$, a positive coefficient that is statistically significant at the 5 percent level could be estimated in ten of the 21 equations only (for four other equations the coefficients are positive, but not significant at the 5 percent level). This might be at least partly attributed to the inclusion of importer-specific effects that also account for country-specific demand structures. Distance seems to have had a more uniform impact: Its estimated coefficient is significantly negative in 19 equations and insignificantly negative in one other. ${ }^{44}$

Examining the commodity-specific coefficients for the treaty dummies in Table 5, we find first of all that for the Cobden dummy - which simply models the conclusion of a commercial treaty-significantly positive effects on trade are only found only in commodity groups in which specific liberalizations as modeled by MFN and Tailor had also had significantly positive effects. As these commodity groups also rank among those with the highest frequencies of commodity-specific stipulations (Table 2), we might safely conclude that these "treaty effects" were - unsurprisingly — driven by underlying specific liberalizations, and that the results for $M F N$ and Tailor are decisive. ${ }^{45}$

We see that $M F N$ and Tailor had significantly positive effects mainly in manufactures that were subject to high duties before 1859: articles of leather and rubber (for example, gloves, purses, saddlery), textiles of wool, cotton and silk, and spirits. There are also significantly positive results for grains and meals and flours, but these should not be overinterpreted, as they refer to a relatively small number of country-pairs only, in which either Germany or Austria-Hungary was always the importer (their mutual preferences on grains should be predominant here). The results from the extended sample reported in Appendix 3 confirm the results of the core sample, and additionally indicate significantly positive effects for the

${ }^{44}$ Commodity group-specific results refer to the PPML-SUR equation system including the variable MFN, but also hold for the other PPML systems with a very small degree of variation.

45 In an earlier version of this article, decomposed net effects of Cobden were assessed. It resulted that - except for linen yarn, the effect of Cobden minus MFN was not significantly positive for all commodity groups. 
remaining cloth category, linens, and for pig iron and steel. ${ }^{46}$ Furthermore, the differences of OLS and PPML estimates are small, which can be taken as an additional indication of robustness of the results. The question whether tailor-made preferences or their transmission and the expansion of the network via $M F N$ drove the results cannot be conclusively answered from Table 5. Only for woolen and worsted yarns do we find positive effects for Tailor, but not for $M F N$, while for three groups of manufactured goods we find the contrary. This indicates that tailor-made preferences might be inadequately captured by the dummies, and further research using more refined measures is recommended. Notwithstanding this, Tables 5 and 6 give firm evidence that the treaties helped to increase trade flows significantly for many commodities, mostly manufactures, while trade with most raw materials, especially the inputs to the respective branches (hides, skins, and leather; wool, silk), experienced no significant benefits.

Given the positive commodity-specific effects, one might ask why they did not lead to consistently positive effects at the aggregate level, and how can the effects be quantified in comparison with aggregate trade in the dataset and aggregate trade covered by treaties. To do this, I estimated a system of equations (2) for the core sample with PPML-SUR as described above, but with simultaneously included period-specific treaty effects as measured by $M F N$, that is, $M F N^{*} D 1861, M F N^{*} D 1863$, and so on. ${ }^{47}$ If the coefficient for these dummies ( $\beta_{\mathrm{MFN} * 1861}, \beta_{\mathrm{MFN} * 1863}$, etc.) was significant at the 5 percent level for a commodity group $k$, it was converted into percent increases in trade attributable to preferential liberalizations, which then were multiplied with actual bilateral imports for country-pairs wherein an $M F N$ preference was in force in the corresponding commodity group. These products have been summed up across commodity groups. The evolving term is called "trade increase due to MFN preferences" $\left(T I_{M F N}\right)$ and formally calculated as

$$
T I_{M F N, \text { year }}=\sum_{k=1}^{21}\left(\exp \left(\beta_{M F N_{k} * \text { year }}\right)-1\right) * I M * M F N_{k} * \text { Year if } p_{\beta_{M F N_{k} y_{\text {year }}}}>0.05 \text {. }
$$

Figure 2 presents the evolution of $T I_{M F N}$ in absolute values and in percent of aggregate bilateral imports between the countries in the core sample that had a Cobden treaty in force in the corresponding year. ${ }^{48}$

46 The inclusion of important producers of these two articles into the extended sample can be seen as driving the results here: Russia was an important exporter of linens, while Sweden and Norway were the second most important providers of bar iron and steel to Europe and among the five main exporters of pig iron (see Lampe, "Bilateral Trade Flows," Table 12).

47 The detailed estimation results are available on request.

48 A similar exercise at the aggregate level that includes time-varying Cobden dummies in equation (1) confirmed my conclusion, as for all Cobden*year variables, only insignificant effects could be estimated. 
We see that significant commodity-specific treaty effects in none of the years sum to more than 32.5 percent of aggregate trade between countries with a bilateral treaty in force. The average was 22.7 percent between 1861 and 1875. The first local maximum, attributable to a one-time effect of the Cobden-Chevalier Treaty in 1861 (28.4 percent) is only reached again at the end of the observation period. ${ }^{49}$ Even the 32.5 percent, in 1875 , would hardly have led to a significant coefficient for Cobden in the aggregate estimates underlying Table $4{ }^{50}$ This confirms the expectation that the treaties hardly produced uniform overall impacts.

[Figure 2 about here]

Up to now, the results confirm our expectation that commodity-specific effects mattered. As stated above, negotiators sought to help their domestic exporters of specific goods, especially manufactures and heavily tariffed alcoholic beverages. A central question is therefore how successful were each country's commercial diplomats in effectively helping to boost domestic exports. The straightforward way to investigate this is to include national exporter-specific effects of $M F N$ liberalizations into the system of equations (2), that is, interaction effects of every country's exporter dummy with $M F N$ (for example, $\left.F R A E X^{*} M F N, Z V E X^{*} M F N\right)$, in the same may as was done above with year-specific interaction terms. The coefficients obtained from these estimates for every country's exporters in each commodity group are presented in Table 7.

[Table 7 about here]

The constrained "average" coefficients in the lower part of that table suggest that France, the Zollverein, Belgium, and Austria-Hungary benefitted significantly from the treaty network, while the average effect is positive, but insignificant for the United Kingdom, and significantly negative for the Netherlands. Again, the p-values from Wald test $\chi^{2}$-statistics indicate that the coefficients were not identical across commodity groups. If we look at these coefficients in the upper part of Table 7, we find significantly positive coefficients mainly for

The February Treaty between Austria-Hungary and the Zollverein (1853-65) has been included in the "percent of trade covered by Cobden" figures.

49 Treaties concluded before 1861 also had no considerable effects. Notably, the effects of comprehensive preferences granted in the 1853 February Treaty between Austria-Hungary and the Zollverein, which was supposed to prepare a future accession of Austria to the Zollverein, were below 10 percent. This underlines that besides a lack of political will for the union of Austria with the Zollverein (especially in Prussia), there seems to have been a rather low potential of benefits to be obtained from the integration.

50 The coefficient for Cobden in the PPML core estimate of Table 4 corresponds to about 48.5 percent. 
manufactured articles: The United Kingdom benefitted significantly in all categories of cloth and in articles of leather and rubber, as did France, with the exception of linens. Additionally, in France as in almost all other countries, exports of spirits and liqueurs rose significantly. German and Austrian exporters benefitted in a variety of industries, while Belgian benefits were concentrated in iron and steel products. For the Netherlands, only the linens coefficient is significantly positive at the 5 percent level for manufactures.

The first three rows of the table indicate numerous positive effects of the treaty network on trade with wheat, rye, and meals and flours. These coefficients, of which some show extremely high values, might at first glance indicate that the real beneficiary of the CobdenChevalier Network was agriculture. Still, these high and positive coefficients actually belong to few preferences and small export volumes in most cases. I suspect that the interaction terms here take up certain idiosyncrasies that could not be controlled for. Additionally, we find some negative coefficients. Most of them indicate sectoral or international specialization, and thus a deepening of the industrial division of labor in Europe: Negative coefficients for woolen and linen yarn in the United Kingdom (and in the Netherlands for linen yarn) are accompanied by significantly positive effects for the corresponding final manufactured product, cloth. Nevertheless, some negative coefficients can be made sense of only by looking at industry-level national developments, which is clearly beyond the scope of this paper.

[Table 8 about here]

To assess the quantitative amount of benefits for each country's exporters, the commodity-group coefficients of Table 7 have been converted into "export increases due to MFN liberalizations by partner countries," as was done above for year-wise estimates, using partner import data for $1875 .^{51}$ Their values (Table 8) show that French exporters benefited most, followed by the Zollverein, Austria-Hungary and Belgium. The export increases for the United Kingdom and Belgium are the smallest in relative terms, and even negative for the Netherlands. From these results on the distribution of gains from the network, we can conclude that it benefitted most those countries whose negotiators primarily aimed at strategically using the treaties to bring down partner tariffs, while the "unilateralists" from Britain and the Netherlands who generalized all preferences even to non-treaty partners and did not participate actively in the expansion of the network, did not share its benefits. Belgium presents a special case because its government used the treaties mainly to bargain for the participation of contract partners in the capitalization of the Scheldt Toll, which, until

51 Because treaty effects were highest in 1875 , the amounts reported in Table 8 are upper-bound estimates. 
1863, was levied by the Dutch government for ships heading into Antwerp, Belgium's major commercial port. ${ }^{52}$

\section{CONCLUSIONS}

This study establishes a new and nuanced picture of the Cobden-Chevalier Network. A close inspection of the individual bilateral treaties and contemporary accounts reveals that the negotiating commercial diplomats were not mere lawn jockeys who mowed equally across all tariff lines. Rather, they should be viewed as skillful gardeners, who aimed to trim specific tariffs in the coppice of partners' tariff regimes, especially those that mattered for domestic exporters of manufactures and budget-sensitive luxury goods, such as alcoholic beverages. Assessing the effects of the treaties, it is shown that previous research was correct about their inefficacy to boost the total trade in Europe, but it was mistaken about the actual effectiveness of commercial diplomacy, regarding its actual goals. Using disaggregated trade data, it can be demonstrated that the treaties were effective in enhancing trade, but not for all commodities. Their effects were most notable in final products, especially textiles. By this, the treaties contributed to the deepening and diversification of intra-European trade.

Exporters from those countries whose governments were driving forces in the formation of the treaty network and which strategically used the treaties to bring down partner tariffs reaped the highest benefits. In form and effect, nineteenth-century bilateralism was ideologically closer to first-difference reciprocity than to the free trade doctrine. Hence, it is an irony of history that it has become identified with the names of Cobden and Chevalier. Instead, French Minister Eugène Rouher or Prussian Commercial Councillor Rudolf von Dellbrück, moderate free-traders with a realpolitik background, would be more aptly named as its patrons.

52 Mahaim, "Politique commerciale." 
Appendix 1

SEALING DATES FOR UNCONDITIONAL MFN TREATIES, 1855-1875

[Table A.1 here]

A very short note on the Treaty of Commerce and Navigation between Italy and Portugal, signed at Lisbon, 15 July 1872 (Parry, ed., Consolidated Treaty Series, Vols. 145, pp. 15-28).

This treaty is not included in the published version of this article (Journal of Economic History, 69, 2009). This does not alter the results of the present study in any way, since neither Italy nor Portugal are importers in the core or extended sample. The treaty contains the unconditional MFN clause, although with reservation of special treatment for Brazil by Portugal (§2). It was to be in force for 4 years, a very short period, with a one-year notification term afterwards (\$27). It stipulated no new preferences for Portuguese articles in Italy, but Portugal granted preferential tariff rates for the following products of Italian origin: Carded hemp: 20 reis per kg; packing or wrapping paper of all kinds: 15 reis per kg, marbles, raw: $1 \%$ ad valorem; Marbles, wrought (lavorati): $1 \%$ ad valorem; Stones not specified, wrought: $1 \%$ ad valorem; Men's hats of all kinds: $20 \%$ ad valorem. As a consequence of the MFN clause, the second column of Table 2 has been slightly updated in comparison to the published version, in the first column only the totals have been changed. Also the total number of treaties and the number of treaties with new preferences has been updated on p. 6 . 
Appendix 2

\section{SOURCES FOR NATIONAL INCOME DATA}

GDPs/GNPs in current prices were obtained from B. R. Mitchell for the United Kingdom, France, the United States, and Denmark. ${ }^{53}$

For "Germany" (Zollverein/Kaiserreich), the NNP compromise estimate by Carsten Burhop and Guntram B. Wolff was used and converted to current prices with Walther G. Hoffmann's implicit deflator. To reconstruct a GNP figure, a constant share of 8.4 percent was added to these figures, following Angus Maddison. ${ }^{54}$ For Belgium, data from Maddison were converted to current prices by the implicit exchange rate for French GNP from Maddison and Mitchell, as practiced by Accominotti and Flandreau. ${ }^{55}$ GNP data of Smits, Horlings, and van Zanden was used for the Netherlands. ${ }^{56}$

Austria-Hungary's GNP was extrapolated using the 1913 sector shares constructed by Max-Stephan Schulze. They were combined with Schulze's data back to 1870, and series for former years by John Komlos for industry and Anton Kausel for the service sector. For agriculture, series reported by László Katus were employed for Hungary, and interpolations based on figures from Roman Sandgruber and Komlos aim to model developments in Austria. The resulting real GDP approximations were converted to current prices by combining Schulze's sector shares with the components of the CPI constructed by Vera Mühlpeck, Sandgruber, and Hannelore Woitek. Finally, territorial changes were accounted for using Rupert Pichler's indirect estimates of regional GDP per capita and the regional population data reported by Birgit Bolognese-Leuchtenmüller. ${ }^{57}$

Data for Switzerland are from Heiner Ritzmann-Blickenstorfer. For Italy, Stefano Fenoaltea's estimate was used and converted to current prices using the implicit GDP deflator of the ISTAT-Vitali estimates reported by Mitchell. National incomes for 1857 and 1859 were extrapolated linearly with the 1861-1870 trend. For Sweden and Norway, individual estimates of both countries were added up. Data for Sweden are from Rodney Edvinsson, and data for Norway from Ola H. Grytten. For Spain, reconstructions by Leandro Prados de la

53 Mitchell, International Historical Statistics.

54 Burhop and Wolff, "Compromise Estimate"; Hoffmann, Wachstum, Tables 248-49; Maddison, "Long-Run Perspective," Data Appendix.

55 Maddison, World Economy, Table 1b; Mitchell, International Historical Statistics; Accominotti and Flandreau, "Bilateral Trade Treaties."

56 Smits, Horlings, and van Zanden, Dutch GNP, Table I.12.

57 Schulze, "Patterns"; Komlos, Habsburg Monarchy; Kausel, “Österreichs Volkseinkommen"; Katus, "Economic Growth"; Sandgruber, Österreichische Agrarstatistik; Komlos, "Austro-Hungarian Agricultural Development"; Mühlpeck, Sandgruber, and Woitek, "Index"; Pichler, Wirtschaft; and BologneseLeuchtenmüller, Bevölkerungsentwicklung. 
Escosura were used, and the national income for Portugal is from the estimate by Anabela Nunes, Eugénia Mata, and Nuno Valério. For Russia, data were extrapolated from a national income series in current prices by Paul Gregory with Raymond Goldsmith's agricultural and industrial production figures (weighting agriculture and industry 9:1, following Gregory). As Goldsmith's figures are for "real" production, the derived figures have been inflated' with the movement of the imputed price index for 1867-1913 by Gregory and Joel W. Sailors, which was trend-extrapolated for former years. The resulting Russian national income guesstimates are, of course, rough approximations only. ${ }^{58}$

Appendix 3:

RESULTS FOR COMMODITY-SPECIFIC BILATERAL TRADE: SUR-CORRECTED OLS AND PPML KEY COEFFICIENT ESTIMATES FROM INDIVIDUAL COMMODITY-GROUP EQUATIONS (2) FOR THE EXTENDED SAMPLE

[Table A.2 and A.3 here]

58 Ritzmann-Blickenstorfer, Historische Statistik; Fenoaltea, "Growth"; Mitchell, International Historical Statistics; Edvinsson, Growth; Grytten, "Gross Domestic Product"; Prados, Progreso; Nunes, Mata, and Valério, "Portuguese Economic Growth"; Gregory, Russian National Income, Tables 3.2 and 5; Goldsmith, "Economic Growth"; Gregory and Sailors, "Russian Monetary Policy." 


\section{REFERENCES}

Accominotti, Olivier, and Marc Flandreau. "Bilateral Trade Treaties and the Most-FavoredNation Clause: The Myth of Trade Liberalization in the Mid-Nineteenth Century." World Politics 60, no. 2 (2008): 147-88.

Anderson, James E., and Eric van Wincoop. "Gravity with Gravitas: A Solution to the Border Puzzle." American Economic Review 93, no. 1 (2003): 170-92.

Bairoch, Paul. "European Trade Policy, 1815-1914." In The Cambridge Economic History of Europe. Vol. 8. The Industrial Economies: The Development of Economic and Social Policies, edited by Peter Mathias and Sidney Pollard, 1-160. Cambridge: Cambridge University Press, 1989.

Baldwin, Richard, and Daria Taglioni. "Gravity for Dummies and Dummies for Gravity Equations.” NBER Working Paper No. 12516, Cambridge, MA, September 2006.

Bhagwati, Jagdish N. "Introduction: The Unilateral Freeing of Trade vs. Reciprocity." In

Going Alone. The Case for Relaxed Reciprocity in Freeing Trade, edited by Jagdish N. Bhagwati, 1-30. Cambridge, MA: MIT Press, 2002.

Bolognese-Leuchtenmüller, Birgit. Bevölkerungsentwicklung und Berufsstruktur,

Gesundheits- und Fürsorgewesen in Österreich, 1750-1918. Wirtschafts- und Sozialstatistik Österreich-Ungarns, vol. 1. München: R. Oldenbourg, 1978.

Brawley, Mark R. Power, Money, and Trade: Decisions That Shape Global Economic Relations. Second edition. Peterborough, ON: Broadview, 2005.

Burhop, Carsten, and Guntram B. Wolff. “A Compromise Estimate of German Net National Product, 1851-1913, and its Implications for Growth and Business Cycles." This JOURNAL 85, no. 3 (2005): 615-57.

Cadier, Gabrielle. "Les conséquences du traité de 1860 sur le commerce franco-britannique." Histoire, économie et société 7, no. 3 (1988): 355-80.

Cameron, A. Colin, and Pravin K. Trivedi. Regression Analysis of Count Data. Econometric Society Monographs, vol. 30. Cambridge: Cambridge University Press, 2003.

Denzel, Markus. Währungen der Welt. Vol. 11. Dänische und nordwestdeutsche Wechselkurse 1696-1914. Stuttgart: Steiner, 1999.

Dunham, Arthur Louis. The Anglo-French Treaty of Commerce of 1860 and the Progress of the Industrial Revolution in France. History and Political Science, vol. 10. Ann Arbor: University of Michigan Press, 1930.

The Economist, 13 February 1869.

Edvinsson, Rodney. Growth, Accumulation, Crisis: With New Macroeconomic Data for Sweden. Stockholm: Almqvist \& Wiksell, 2005. 
Ejrnæs, Mette, and Karl Gunnar Persson. "Market Integration and Transport Costs in France 1825-1903: A Threshold Error Correction Approach to the Law of One Price." Explorations in Economic History 37, no. 2 (2000): 149-73.

Fenoaltea, Stefano. "The Growth of the Italian Economy, 1861-1913: Preliminary SecondGeneration Estimates.” European Review of Economic History 9, no. 3 (2005), 273312.

Glier, Lorenz. Die Meistbegünstigungs-Klausel. Eine entwickelungsgeschichtliche Studie unter besonderer Berücksichtigung der deutschen Verträge mit den Vereinigten Staaten von Amerika und Argentinien. Veröffentlichungen des Mitteleuropäischen Wirtschaftsvereins, vol. 2. Berlin: Puttkammer \& Mühlbrecht, 1905.

Goldsmith, Raymond. "The Economic Growth of Tsarist Russia, 1860-1913." Economic Development and Cultural Change 9, no. 3 (1961): 441-75.

Gregory, Paul R. Russian National Income, 1885-1913. Cambridge: Cambridge University Press, 1982.

Gregory, Paul R., and Joel W. Sailors. "Russian Monetary Policy and Industrialization, 18611913.” This JOURNAL 36, no. 4 (1976): 836-51.

Grytten, Ola H. "The Gross Domestic Product for Norway 1830-2003." In Historical Monetary Statistics for Norway 1819-2003. Norges Bank Occasional Papers, vol. 35, edited by Øyvind Eitrheim, Jan T. Klovland and Jan F. Qvigstad, 241-88. Oslo: Norges Bank, 2004.

Helleiner, Karl F. Free Trade and Frustration: Anglo-Austrian Negotiations 1860-70. Toronto: University of Toronto Press, 1973.

Henningsen, Arne, and Jeff D. Hamann. "systemfit: A Package for Estimating Systems of Simultaneous Equations in R", Journal of Statistical Software 23, no. 4 (2007). http://www.jstatsoft.org/v23/i04.

Hoffmann, Walther G. Das Wachstum der deutschen Wirtschaft seit der Mitte des 19. Jahrhunderts. Berlin: De Gruyter, 1965.

Horlings, Edwin. "The International Trade of a Small and Open Economy. Revised Estimates of the Imports and Exports of Belgium, 1835-1990.” NEHA-Jaarboek 65 (2002): 110 42.

Howe, Anthony. Free Trade and Liberal England, 1846-1946. Oxford: Clarendon, 1997.

Humphrey, David H. "Disaggregated Import Functions for the UK, West Germany and France." Oxford Bulletin of Economics \& Statistics 38, no. 4 (1976): 281-98.

Iliasu, Asaana. "The Cobden-Chevalier Commercial Treaty of 1860." Historical Journal 14, no. 1 (1971): 67-98.

Irwin, Douglas A. "Free Trade and Protection in Nineteenth-Century Britain and France Revisited: A Comment on Nye", This JOURNAL 53, no. 1 (1993): 146-52. 
- "Multilateral and Bilateral Trade Policies in the World Trading System: An Historical Perspective.” In New Dimensions in Regional Integration, edited by Jaime de Melo and Arvind Panagariya, 90-119. Cambridge: Cambridge University Press, 1993. Jacks, David. "Intra- and International Commodity Market Integration in the Atlantic Economy, 1800-1913.” Explorations in Economic History 42, no. 3 (2005): 381-413.

Katus, László. "Economic Growth in Hungary During the Age of Dualism (1867-1913). A Quantitative Analysis." In Social-Economic Researches on the History of East-Central Europe., Studia Historica Academiae Scientiarum Hungaricae, vol. 62, edited by Gyúla Ranki et. al., 35-127. Budapest: Akadémiai Kiadó, 1970.

Kaukiainen, Yrjö. "Shrinking the World: Improvements in the Speed of Information Transmission, c. 1820-1870." European Review of Economic History 5, no. 1 (2001): $1-28$.

Kausel, Anton. “Österreichs Volkseinkommen 1830 bis 1913, Versuch einer Rückrechnung des realen Brutto-Inlandsprodukts für die österreichische Reichshälfte und das Gebiet der Republik Österreich." In Geschichte und Ergebnisse der zentralen amtlichen Statistik in Österreich 1829-1979. Festschrift aus Anlaß des 150jährigen Bestehens der zentralen amtlichen Statistik in Österreich, edited by Österreichisches Statistisches Zentralamt, 689-720. Wien: Österreichische Staatsdruckerei, 1979.

Keller, Wolfgang, and Carol H. Shiue. "Tariffs, Trains, and Trade: The Role of Institutions versus Technology in the Expansion of Markets." NBER Working Paper No. 13913. Cambridge, MA, April 2008.

Komlos, John. “Austro-Hungarian Agricultural Development, 1827-1877." Journal of European Economic History 8, no. 1 (1979): 37-60.

. The Habsburg Monarchy as a Customs Union. Economic Development in AustriaHungary in the Nineteenth Century. Princeton, NJ: Princeton University Press, 1983.

Konno, Toru, and Mototsugu Fukushige. "The Canada-United States Bilateral Import Demand Functions: Gradual Switching in Long-Run Relationships." Applied Economics Letters 9, no. 9 (2002): 567-70.

Lampe, Markus. "Bilateral Trade Flows in Europe, 1857-1875. A New Dataset.” Research in Economic History 26 (2008): 81-155.

Lazer, David A. “The Free Trade Epidemic of the 1860's and other Outbreaks of Economic Discrimination." World Politics 51, no. 4 (1999): 447-83.

Levi, Leone. "Statistical Results of the Recent Treaties of Commerce between Different States of Europe.” Journal of the Statistical Society 40, no. 1 (1877): 1-18.

Lindblad, J. Thomas, and Jan L. van Zanden. "De buitenlandse handel van Nederland, 18721913." Economisch- en Sociaal-Historisch Jaarboek 52 (1989): 231-69. 
López-Córdova, J. Ernesto, and Christopher M. Meissner. "Exchange Rate Regimes and International Trade: Evidence from the Classical Gold Standard Era." American Economic Review 93, no. 1 (2003): 344-53.

Maddison, Angus. "A Long-Run Perspective on Saving." Scandinavian Journal of Economics 94, no. 2 (1992): 181-96. Data Appendix available online at http://www.ggdc.net/ maddison/ARTICLES/Savings/AppxText.pdf.

Maddison, Angus. The World Economy. Paris: OECD, 2006.

Mahaim, Ernest. "La politique commerciale de la Belgique." In Die Handelspolitik der wichtigeren Kulturstaaten in den letzten Jahrzehnten. Vol. 1. Schriften des Vereins für Socialpolitik, vol. 49, edited by Verein für Socialpolitik, 195-238. Leipzig: Duncker \& Humblot, 1892.

Marsh, Peter T. Bargaining on Europe. Britain and the First Common Market, 1860-1892. New Haven, CT: Yale University Press, 1999.

Mitchell, B. R. International Historical Statistics. Vols. Europe, 1750-2000 and The Americas, 1750-2000 . Houndmills: Palgrave Macmillan, 2003.

Mühlpeck, Vera, Roman Sandgruber, and Hannelore Woitek. "Index der Verbraucherpreise 1800 bis 1914. Eine Rückberechnung für Wien und den Gebietsstand des heutigen Österreich." In Geschichte und Ergebnisse der zentralen amtlichen Statistik in Österreich 1829-1979. Festschrift aus Anlaß des 150jährigen Bestehens der zentralen amtlichen Statistik in Österreich, edited by Österreichisches Statistisches Zentralamt, 649-88. Wien: Österreichische Staatsdruckerei, 1979.

Nunes, Anabela, Eugénia Mata and Nuno Valério. "Portuguese Economic Growth, 18331985." European Journal of Economic History 18, no. 2 (1989): 291-330.

Nye, J. Vincent. "The Myth of Free Trade Britain and Fortress France: Tariffs and Trade in the Nineteenth Century." This Journal 51, no. 1 (1991): 23-46.

. "Changing French Trade Conditions, National Welfare, and the 1860 Anglo-French Treaty of Commerce." Explorations in Economic History 28, no. 4 (1991): 460-77.

War, Wine, and Taxes. The Political Economy of Anglo-French Trade, 1689-1900. Princeton Economic History of the Western World Princeton, NJ: Princeton University Press, 2007.

O'Rourke, Kevin H., and Jeffrey G. Williamson. Globalization and History. Cambridge: Cambridge University Press, 1999.

Pahre, Robert. Politics and Trade Cooperation in the Nineteenth Century: The 'Agreeable Customs' of 1815-1914. Cambridge: Cambridge University Press, 2008.

Parry, Clive, ed. The Consolidated Treaty Series, 231 vols., Dobbs Ferry, NY: Oceana, 1969. 
Pichler, Rupert. Die Wirtschaft der Lombardei als Teil Österreichs. Wirtschaftspolitik, Außenhandel und industrielle Interessen 1815-1859. Schriften des ItalienischDeutschen Historischen Instituts in Trient, vol. 9. Berlin: Duncker \& Humblot, 1996.

Prados de la Escosura, Leandro. El progreso económico de España (1850-2000). Bilbao: Fundación BBVA, 2003.

Preußisches Handelsarchiv, various dates.

Ritzmann-Blickenstorfer, Heiner. Historische Statistik der Schweiz-Statistique historique de la Suisse-Historical Statistics of Switzerland. Zürich: Chronos, 1996.

Rose, Andrew K. "Do We Really Know That the WTO Increases Trade?" American Economic Review 94, no. 1 (2004): 98-114.

Sandgruber, Roman. Österreichische Agrarstatistik 1750-1918. Wirtschafts- und Sozialstatistik Österreich-Ungarns, vol. 2. München: R. Oldenbourg, 1978.

Santos Silva, J.M.C., and Silvana Tenreyro. "The Log of Gravity." The Review of Economics and Statistics 88, no. 4 (2006): 641-58.

Schneider, Jürgen, Oskar Schwarzer and Friedrich Zellfelder. Währungen der Welt. Vol. 1. Europäische und nordamerikanische Devisenkurse 1777-1914, Stuttgart: Steiner, 1991.

Schulze, Max-Stephan. "Patterns of Growth and Stagnation in the Late Nineteenth Century Habsburg Economy." European Review of Economic History 4, no. 3 (2000): 311-40.

Shiue, Carol H. "From Political Fragmentation towards a Customs Union: Border Effects of the German Zollverein, 1815 to 1855." European Review of Economic History 9, no. 2 (2005): 129-62.

Smits, Jan-Pieter, Edwin Horlings, and Jan L. van Zanden. Dutch GNP and its Components, 1800-1913. GGDC Research Memorandum, vol. 5. Groningen: Groningen Growth and Development Centre, 2000.

Stein, Arthur A. “The Hegemon's Dilemma: Great Britain, the United States, and the International Economic Order.” International Organization 38, no. 2 (1982): 355-86.

Subramanian, Arvind, and Shang-Jin Wei. "The WTO Promotes Trade, Strongly but Unevenly." Journal of International Economics 72, no. 1 (2007): 151-75.

Weesie, Jeroen. "sg121: Seemingly Unrelated Estimation and the Cluster-Adjusted Sandwich Estimator." Stata Technical Bulletin no. 52 (1999): 34-47. http://statapress.com/journals/stbcontents/stb52.html.

Wendt, Bernd-Jürgen. "Freihandel und Friedenssicherung. Zur Bedeutung des CobdenVertrags von 1860 zwischen Frankreich und England." Vierteljahrschrift für Sozial- und Wirtschaftsgeschichte 61, no. 1 (1974): 29-64. 
Table 1

AD VALOREM EQUIVALENTS OF TARIFF RATES FOR MAJOR COMMODITY GROUPS IN 1859 (PERCENT)

\begin{tabular}{|c|c|c|c|c|c|c|c|}
\hline & UK & France & Zollverein & Belgium & Netherlands & $\begin{array}{l}\text { Austria- } \\
\text { Hungary }\end{array}$ & USA \\
\hline Wheat & 2.3 & 1.1 & 2.2 & 2.5 & 0.0 & 1.0 & 15.0 \\
\hline Rye & 3.2 & 1.7 & 0.7 & 3.6 & 0.1 & 2.5 & 15.0 \\
\hline Milling prod. & 2.6 & 2.2 & 2.4 & 3.6 & 1.0 & 1.2 & 13.3 \\
\hline Wood & 8.1 & 0.8 & 0.7 & 5.8 & 1.3 & 0.3 & 24.0 \\
\hline $\begin{array}{l}\text { Hides, skins, } \\
\text { and leather }\end{array}$ & 0.0 & 0.8 & 0.4 & 0.2 & 1.0 & 1.2 & 6.7 \\
\hline Wool & 0.0 & 5.9 & 0.0 & 0.0 & 0.0 & 0.0 & 1.2 \\
\hline Silk & 0.0 & 0.4 & 0.2 & 0.3 & 0.0 & 0.5 & 3.9 \\
\hline Pig iron & 0.0 & 19.2 & 30.4 & 10.0 & 0.0 & 15.5 & 24.0 \\
\hline $\begin{array}{l}\text { Bar iron and } \\
\text { steel }\end{array}$ & 0.0 & 10.1 & 31.2 & 3.3 & 0.0 & 21.1 & 17.8 \\
\hline Ironware & 10.8 & 33.2 & 31.0 & 22.6 & 3.6 & 16.5 & 19.8 \\
\hline $\begin{array}{l}\text { Articles of } \\
\text { leather/rubber }\end{array}$ & 12.6 & 11.6 & 2.1 & 24.8 & 5.1 & 2.5 & 24.0 \\
\hline Woolen yarn & 1.0 & 80.0 & 1.7 & 8.1 & 2.4 & 3.6 & 19.0 \\
\hline $\begin{array}{l}\text { Woolens and } \\
\text { worsteds }\end{array}$ & 0.1 & 48.1 & 10.4 & 14.9 & 3.3 & 17.5 & 21.7 \\
\hline Cotton yarn & 0.0 & 36.1 & 10.1 & 4.6 & 1.1 & 6.5 & 19.0 \\
\hline Cottons & 0.7 & 21.3 & 56.5 & 19.1 & 4.1 & 29.1 & 24.0 \\
\hline Linen yarn & 0.0 & 21.5 & 4.8 & 0.5 & 1.1 & 3.4 & 15.0 \\
\hline Linens & 0.4 & 19.1 & 3.7 & 31.5 & 1.2 & 15.2 & 15.0 \\
\hline Silk wares & 10.7 & 9.0 & 9.4 & 5.1 & 3.8 & 14.0 & 19.0 \\
\hline $\begin{array}{l}\text { Glass and } \\
\text { glassware }\end{array}$ & 2.0 & 42.5 & 5.9 & 12.1 & 5.8 & 2.5 & 21.0 \\
\hline Wines & 89.4 & 0.5 & 62.9 & 0.6 & 0.1 & 27.6 & 30.0 \\
\hline $\begin{array}{l}\text { Spirits and } \\
\text { liqueurs }\end{array}$ & 176.0 & 12.3 & 49.5 & 9.2 & 0.0 & 37.1 & 30.0 \\
\hline $\begin{array}{l}\text { Export- } \\
\text { weighted } \\
\text { average }\end{array}$ & 8.9 & 18.7 & 14.7 & 9.3 & 2.0 & 10.9 & 17.6 \\
\hline $\begin{array}{l}\text { Overall } \\
\text { average tariff }\end{array}$ & 16.3 & 11.8 & 7.1 & 3.2 & 1.2 & 7.3 & 15.8 \\
\hline
\end{tabular}

Source: Lampe, "Bilateral Trade Flows," Table 13.

Note: Overall average tariff: Ratio of duties recollected to total imports for home consumption. Export weighted average tariff: commodity-group tariff rates weighted by an unweighted average of every country's average export shares for each commodity group in 1865. Imports for home consumption for the UK and the US = imports - re-exports. "Silk wares" include fine textiles made from other fibres. US tariff rates exclude imports of raw material that entered free of duty from Canada and other British Provinces in North America under the Elgin-Marcy Treaty (in force 1854-1866); taking into account these duty-free imports, ad valorem equivalent average tariffs decrease to $0.1 \%$ for wheat, $0.0 \%$ for rye, $0.2 \%$ for milling products, $6.6 \%$ for hides, skins and leather, $0.0 \%$ for wood and $1.1 \%$ for wool. Tariff rates for spirits and liqueurs were corrected for domestic excises and production taxes which were included in the official customs duties of some countries, but not of others, and are now "tariff only". 
Table 2

FREQUENCIES OF PREFERENTIAL AND MFN-LIBERALIZATIONS ACCORDING TO COMMODITY GROUPS IN COMMERCIAL TREATIES WITH UNCONDITIONAL MFN CLAUSES, 1855-1875

\begin{tabular}{|c|c|c|}
\hline Commodity group & $\begin{array}{l}\text { No. of tailor-made } \\
\text { preferences in bilateral } \\
\text { treaties }\end{array}$ & $\begin{array}{l}\text { No. of country-pairs with } \\
\text { MFN liberalizations } \\
\text { through treaties } \\
\text { concluded until } 1875\end{array}$ \\
\hline Wheat & 1 & 18 \\
\hline Rye & 1 & 18 \\
\hline Milling products & 2 & 18 \\
\hline Wood & 9 & 66 \\
\hline Hides, skins, and leather & 13 & 67 \\
\hline Wool & 10 & 66 \\
\hline Silk & 8 & 73 \\
\hline Pig iron & 9 & 60 \\
\hline Bar iron and steel & 11 & 65 \\
\hline Ironware & 11 & 79 \\
\hline Articles of leather and rubber & 12 & 79 \\
\hline Woolen yarn & 8 & 65 \\
\hline Woolens and worsteds & 13 & 79 \\
\hline Cotton yarn & 10 & 65 \\
\hline Cottons & 12 & 73 \\
\hline Linen yarn & 11 & 73 \\
\hline Linens & 14 & 73 \\
\hline Silk wares & 16 & 79 \\
\hline Glass and glassware & 13 & 65 \\
\hline Wines & 14 & 83 \\
\hline Spirits and liqueurs & 10 & 77 \\
\hline Total no. of country-pairs & 112 & 102 \\
\hline
\end{tabular}

Source: Based on treaty texts in Parry, ed., Consolidated Treaty Series, Vols. 120-150.

Note: Totals in both columns differ because five country-pairs signed two treaties in the observation period. See also the short note to appendix 1 . 
Table 3

AD VALOREM EQUIVALENTS OF TARIFF RATES FOR MAJOR COMMODITY GROUPS IN 1875 (PERCENT)

\begin{tabular}{|c|c|c|c|c|c|c|c|}
\hline & UK & France & Germany & Belgium & Netherlands & $\begin{array}{l}\text { Austria- } \\
\text { Hungary }\end{array}$ & USA \\
\hline Wheat & 0.0 & 1.5 & 0.0 & 0.0 & 0.5 & 0.2 & 17.7 \\
\hline Rye & 0.0 & 0.0 & 0.0 & 0.0 & 0.7 & 0.7 & 9.6 \\
\hline Milling prod. & 0.0 & 1.8 & 0.0 & 0.0 & 2.2 & 0.1 & 15.5 \\
\hline Wood & 0.0 & 0.1 & 0.0 & 5.0 & 1.6 & 0.2 & 16.2 \\
\hline $\begin{array}{l}\text { Hides, skins, } \\
\text { and leather }\end{array}$ & 0.0 & 0.3 & 0.7 & 0.3 & 0.2 & 1.4 & 5.4 \\
\hline Wool & 0.0 & 0.2 & 0.0 & 0.0 & 0.0 & 0.0 & 35.5 \\
\hline Silk & 0.0 & 0.1 & 0.0 & 0.0 & 0.3 & 0.1 & 0.3 \\
\hline Pig iron & 0.0 & 7.5 & 0.0 & 3.5 & 0.0 & 10.0 & 28.9 \\
\hline $\begin{array}{l}\text { Bar iron and } \\
\text { steel }\end{array}$ & 0.0 & 6.2 & 8.8 & 2.4 & 0.0 & 19.6 & 23.2 \\
\hline Ironware & 0.0 & 11.7 & 7.0 & 4.3 & 2.4 & 13.5 & 35.4 \\
\hline $\begin{array}{l}\text { Articles of } \\
\text { leather/rubber }\end{array}$ & 0.0 & 4.9 & 2.3 & 9.6 & 5.0 & 2.5 & 47.8 \\
\hline Woolen yarn & 0.0 & 4.7 & 1.0 & 2.5 & 0.2 & 1.2 & 70.9 \\
\hline $\begin{array}{l}\text { Woolens and } \\
\text { worsteds }\end{array}$ & 0.0 & 10.0 & 8.1 & 10.0 & 5.0 & 7.7 & 63.1 \\
\hline Cotton yarn & 0.0 & 9.3 & 5.9 & 2.3 & 0.1 & 4.5 & 51.0 \\
\hline Cottons & 0.0 & 13.6 & 17.2 & 7.8 & 5.0 & 9.9 & 39.0 \\
\hline Linen yarn & 0.0 & 7.8 & 2.1 & 0.1 & 0.5 & 1.1 & 35.4 \\
\hline Linens & 0.0 & 11.7 & 4.2 & 7.7 & 3.7 & 3.5 & 35.5 \\
\hline Silk wares & 0.0 & 4.4 & 4.0 & 3.7 & 5.0 & 4.7 & 53.7 \\
\hline $\begin{array}{l}\text { Glass and } \\
\text { glassware }\end{array}$ & 0.0 & 7.7 & 7.7 & 9.6 & 4.2 & 4.1 & 43.0 \\
\hline Wines & 26.8 & 10.7 & 19.8 & 0.5 & 0.0 & 18.5 & 68.5 \\
\hline $\begin{array}{l}\text { Spirits and } \\
\text { liqueurs }\end{array}$ & 10.4 & 2.8 & 21.1 & 12.7 & 6.9 & 10.7 & 94.6 \\
\hline $\begin{array}{l}\text { Export- } \\
\text { weighted } \\
\text { average }\end{array}$ & 0.9 & 5.9 & 5.4 & 4.3 & 2.6 & 4.9 & 38.8 \\
\hline $\begin{array}{l}\text { Overall } \\
\text { average tariff }\end{array}$ & 6.3 & 6.5 & 2.5 & 1.6 & 0.7 & 3.6 & 30.8 \\
\hline
\end{tabular}


Table 4

ESTIMATE OF EQUATION (1): MFN TREATIES AND AGGREGATE BILATERAL TRADE (SUM OF COMMODITY GROUPS), COEFFICIENTS FOR OLS AND PPML ESTIMATES (P-VALUES IN PARENTHESES)

\begin{tabular}{lrrrr}
\hline & OLS core & PPML core & OLS extended & PPML extended \\
\hline Constant & -16.16 & -20.98 & -10.61 & -10.97 \\
& $(0.000)$ & $(0.000)$ & $(0.000)$ & $(0.000)$ \\
$\ln \left(\mathrm{Y}_{\mathrm{i}} \mathrm{Y}_{\mathrm{j}}\right)$ & 0.99 & 1.12 & 0.82 & 0.84 \\
& $(0.000)$ & $(0.000)$ & $(0.000)$ & $(0.000)$ \\
$\ln \left(\mathrm{Y}_{\mathrm{i}} / \mathrm{Pop}_{\mathrm{i}}{ }^{*} \mathrm{Y}_{\mathrm{j}} / \mathrm{Pop}_{\mathrm{j}}\right)$ & 0.722 & 0.552 & 0.202 & -0.078 \\
& $(0.000)$ & $(0.000)$ & $(0.119)$ & $(0.435)$ \\
$\ln \left(\mathrm{D}_{\mathrm{ij}}\right)$ & -1.12 & -0.67 & -0.86 & -0.50 \\
& $(0.000)$ & $(0.000)$ & $(0.000)$ & $(0.000)$ \\
Border & 0.68 & 0.25 & 1.22 & 0.27 \\
& $(0.008)$ & $(0.070)$ & $(0.000)$ & $(0.011)$ \\
Language & 0.65 & 0.77 & 0.74 & 0.87 \\
& $(0.000)$ & $(0.000)$ & $(0.000)$ & $(0.000)$ \\
Civil War & -0.03 & 0.10 & -0.19 & -0.15 \\
& $(0.886)$ & $(0.621)$ & $(0.445)$ & $(0.513)$ \\
European War & -0.12 & -0.26 & 0.04 & -0.20 \\
& $(0.622)$ & $(0.088)$ & $(0.862)$ & $(0.282)$ \\
Cobden & 0.13 & 0.28 & -0.04 & 0.00 \\
& $(0.429)$ & $(0.049)$ & $(0.747)$ & $(0.967)$ \\
Adj. $\mathrm{R}^{2} /$ Pseudo- $\mathrm{R}^{2}$ & 0.67 & 0.80 & 0.58 & 0.68 \\
Observations & 420 & 420 & 872 & 880 \\
\hline
\end{tabular}

Source: See text

Notes: Dependent variable: $\ln \left(I M_{i j t}\right)$ for OLS; $I M_{i j t}$ for PPML. "Core" refers to core sample as described above, "Extended" to extended sample. Coefficients for importer and period fixed effects not reported. All estimates with robust standard errors (for clustering by country-pairs). 
Table 5

RESULTS FOR COMMODITY-SPECIFIC BILATERAL TRADE: SUR-CORRECTED OLS AND PPML TREATY DUMMY ESTIMATES FROM INDIVIDUAL COMMODITYGROUP EQUATIONS (2) FOR THE CORE SAMPLE

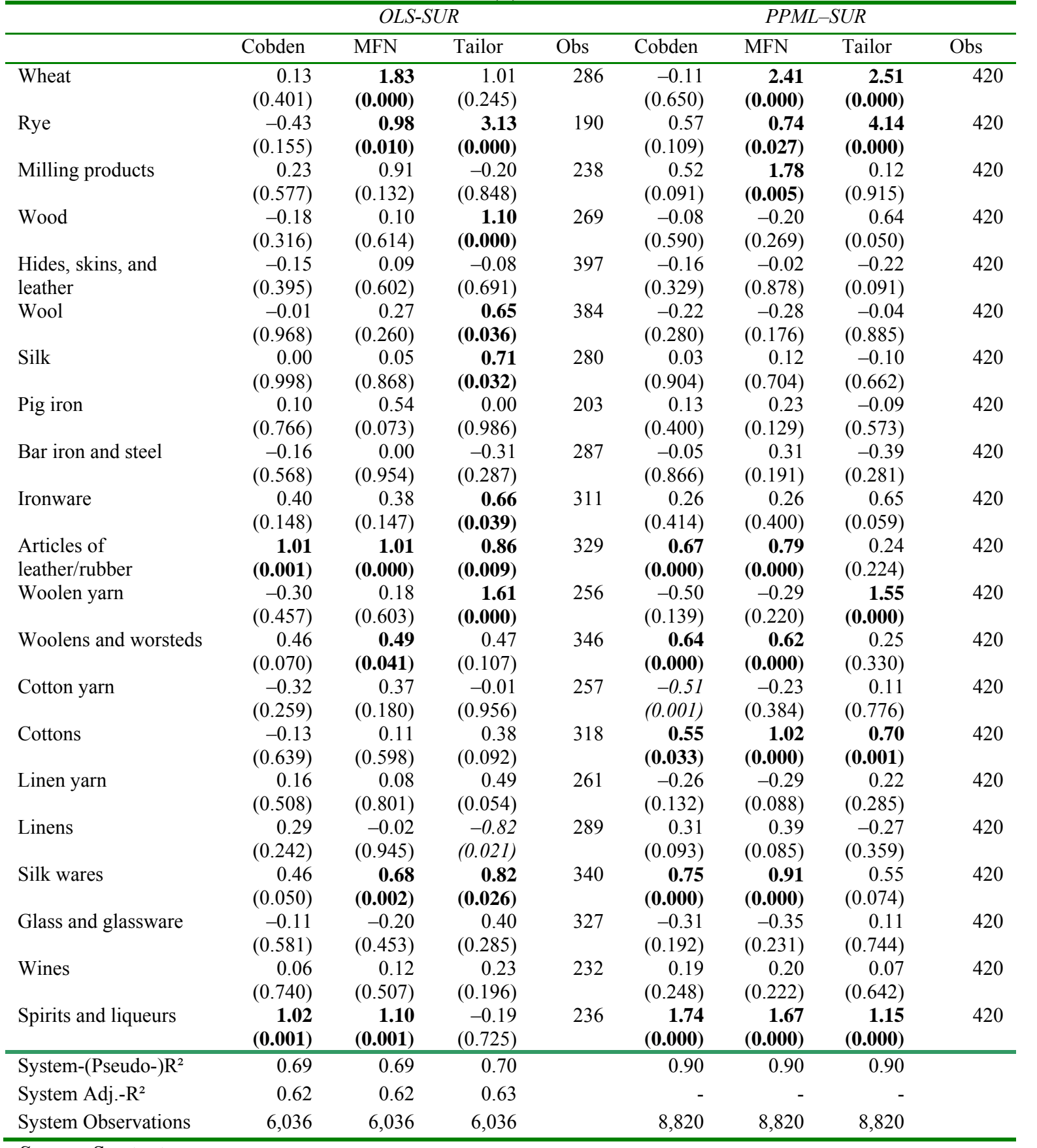

Source: See text

Notes: Dependent variable: $\ln \left(I M_{i j t}\right)$ for OLS-SUR and $I M_{i j t}$ for PPML-SUR; observations $<£ 1,000$ omitted for OLS. Significantly positive coefficients for a confidence interval of $5 \%$ are printed bold, significantly negative coefficients italicized. System- $\mathrm{R}^{2}$ for OLS was calculated as documented in the source code by Henningsen and Hamann, "systemfit," as $O L S R=1-\frac{\sum_{1}^{21} R S S}{\sum_{1}^{21} S S_{\text {Total }}}$, where 1-21 are the commodity group equations, $R S S$ are the residual sums of squares, and $S S_{\text {Total }}$ are the total sums of squares. Adjusted System-OLS-R ${ }^{2}$ thus was calculated accordingly using total system observations and total number of coefficients in the system. System- 
Pseudo- $\mathrm{R}^{2}$ for PPML was analogously calculated as $P P M L-P$ seudo $-R^{2}=1-\frac{\sum_{1}^{21} l l}{\sum_{1}^{21} l l 0}$ where $l l$ is the log-likelihood of each estimation and $l l 0$ the log-likelihood of the corresponding constant-only model; as the Pseudo- $\mathrm{R}^{2}$ is not sensitive to the number of regressors, no adjusted version is needed; see Cameron and Trivedi, Regression Analysis, pp. 153-55). 
Table 6

AVERAGE COEFFICIENTS FOR KEY VARIABLES FROM INDIVIDUAL COMMODITY-GROUP ESTIMATES OF EQUATIONS (2)

\begin{tabular}{|c|c|c|c|c|c|c|}
\hline \multicolumn{7}{|c|}{ Simultaneously constrained coefficients (p-values) [Wald test p-values] } \\
\hline Model & \multicolumn{3}{|c|}{$O L S-S U R$} & \multicolumn{3}{|c|}{$P P M L-S U R$} \\
\hline Treaty dummy & Cobden & MFN & Tailor & Cobden & MFN & Tailor \\
\hline \multirow[t]{3}{*}{$\ln \left(\mathrm{Y}_{\mathrm{i}}\right)_{\mathrm{t}}$} & 0.75 & 0.77 & 0.63 & 0.52 & 0.42 & 0.06 \\
\hline & $(0.000)$ & $(0.000)$ & (0.000) & $(0.000)$ & $(0.000)$ & $(0.313)$ \\
\hline & {$[0.000]$} & {$[0.000]$} & {$[0.000]$} & {$[0.000]$} & {$[0.000]$} & {$[0.000]$} \\
\hline \multirow[t]{3}{*}{$\ln \left(\mathrm{D}_{\mathrm{ij}}\right)$} & -0.68 & -0.66 & -0.52 & -0.53 & -0.49 & -0.33 \\
\hline & $(0.000)$ & $(0.000)$ & $(0.000)$ & $(0.000)$ & $(0.000)$ & $(0.000)$ \\
\hline & {$[0.001]$} & {$[0.002]$} & {$[0.010]$} & {$[0.000]$} & {$[0.000]$} & [0.000] \\
\hline \multirow[t]{3}{*}{ Border } & 0.22 & 0.17 & 0.20 & 0.27 & 0.33 & -0.05 \\
\hline & $(0.000)$ & $(0.044)$ & (0.017) & $(0.000)$ & $(0.000)$ & $(0.369)$ \\
\hline & {$[0.007]$} & [0.004] & {$[0.003]$} & {$[0.000]$} & {$[0.000]$} & [0.000] \\
\hline \multirow[t]{3}{*}{ Language } & 0.95 & 0.95 & 0.94 & 0.95 & 0.96 & 1.09 \\
\hline & $(0.000)$ & $(0.000)$ & $(0.000)$ & $(0.000)$ & $(0.000)$ & (0.000) \\
\hline & {$[0.000]$} & {$[0.000]$} & {$[0.000]$} & {$[0.000]$} & {$[0.000]$} & {$[0.000]$} \\
\hline \multirow[t]{3}{*}{ European War } & -0.10 & -0.07 & -0.05 & -0.08 & -0.13 & -0.12 \\
\hline & $(0.023)$ & $(0.141)$ & $(0.250)$ & (0.012) & $(0.000)$ & $(0.000)$ \\
\hline & {$[0.071]$} & {$[0.076]$} & [0.085] & {$[0.000]$} & {$[0.000]$} & {$[0.000]$} \\
\hline \multirow[t]{3}{*}{ Civil War } & 0.01 & -0.01 & 0.03 & -0.13 & -0.14 & -0.20 \\
\hline & $(0.808)$ & $(0.762)$ & $(0.547)$ & $(0.000)$ & $(0.000)$ & $(0.000)$ \\
\hline & {$[0.005]$} & {$[0.008]$} & {$[0.002]$} & {$[0.000]$} & {$[0.000]$} & [0.000] \\
\hline \multirow[t]{3}{*}{ Cobden/MFN/Tailor } & 0.07 & 0.28 & 0.38 & 0.19 & 0.35 & 0.26 \\
\hline & $(0.136)$ & $(0.000)$ & $(0.000)$ & $(0.000)$ & $(0.000)$ & $(0.000)$ \\
\hline & {$[0.001]$} & {$[0.000]$} & {$[0.000]$} & {$[0.000]$} & {$[0.000]$} & [0.000] \\
\hline
\end{tabular}

Source: See text

Note: See text and Table 5. 
Table 7

RESULTS FOR COMMODITY-SPECIFIC BILATERAL TRADE: ESTIMATED COEFFICIENTS FOR INTERACTION TERMS OF MFN AND EXPORTER DUMMY (PVALUES IN BRACKETS) SIMULTANEOUSLY INCLUDED IN INDIVIDUAL COMMODITY GROUP ESTIMATES OF EQUATION (2) IN ONE SYSTEM, ESTIMATED AS PPML-SUR

\begin{tabular}{|c|c|c|c|c|c|c|}
\hline & UK & France & Zollverein & Belgium & Netherlands & $\begin{array}{l}\text { Austria- } \\
\text { Hungary }\end{array}$ \\
\hline \multirow[t]{2}{*}{ Wheat } & 0.88 & 2.86 & 2.06 & 4.19 & 3.39 & 2.39 \\
\hline & $(0.281)$ & $(0.000)$ & $(0.000)$ & $(0.000)$ & $(0.000)$ & $(0.000)$ \\
\hline \multirow[t]{2}{*}{ Rye } & -0.40 & 0.12 & 18.60 & 0.96 & -6.48 & 3.80 \\
\hline & $(0.386)$ & $(0.622)$ & $(0.000)$ & $(0.000)$ & $(0.000)$ & $(0.000)$ \\
\hline \multirow[t]{2}{*}{ Milling prod. } & 0.80 & 3.25 & 1.03 & 2.11 & 1.17 & -0.68 \\
\hline & $(0.374)$ & $(0.001)$ & $(0.329)$ & $(0.017)$ & $(0.274)$ & $(0.561)$ \\
\hline \multirow[t]{2}{*}{ Wood } & -0.48 & 0.89 & -0.40 & 0.40 & -0.12 & -0.25 \\
\hline & $(0.510)$ & $(0.016)$ & $(0.059)$ & $(0.251)$ & $(0.627)$ & $(0.712)$ \\
\hline \multirow{2}{*}{$\begin{array}{l}\text { Hides, skins, and } \\
\text { leather }\end{array}$} & 0.05 & -0.64 & 0.37 & 0.33 & -0.35 & 0.36 \\
\hline & $(0.794)$ & $(0.022)$ & $(0.173)$ & $(0.099)$ & $(0.355)$ & $(0.520)$ \\
\hline \multirow[t]{2}{*}{ Wool } & -0.32 & 0.72 & -0.29 & 0.38 & -0.53 & -0.83 \\
\hline & $(0.409)$ & $(0.072)$ & $(0.198)$ & $(0.125)$ & $(0.016)$ & (0.039) \\
\hline \multirow[t]{2}{*}{ Silk } & -0.44 & 0.49 & 1.55 & 1.60 & 0.66 & 1.73 \\
\hline & $(0.116)$ & $(0.084)$ & $(0.000)$ & $(0.011)$ & $(0.116)$ & $(0.000)$ \\
\hline \multirow[t]{2}{*}{ Pig iron } & 0.27 & -0.76 & 0.91 & -0.59 & -0.33 & 0.58 \\
\hline & $(0.100)$ & $(0.217)$ & $(0.006)$ & $(0.239)$ & $(0.477)$ & $(0.220)$ \\
\hline \multirow[t]{2}{*}{ Bar iron and steel } & 0.05 & 0.81 & -0.23 & 1.68 & -0.81 & 1.43 \\
\hline & $(0.887)$ & $(0.257)$ & $(0.723)$ & $(0.000)$ & $(0.381)$ & $(0.078)$ \\
\hline \multirow[t]{2}{*}{ Ironware } & 0.09 & 0.48 & 0.15 & 0.80 & -0.50 & 1.44 \\
\hline & $(0.830)$ & $(0.139)$ & $(0.703)$ & $(0.020)$ & $(0.275)$ & $(0.078)$ \\
\hline \multirow{2}{*}{$\begin{array}{l}\text { Articles of } \\
\text { leather/rubber }\end{array}$} & 1.07 & 0.47 & 1.45 & 0.15 & 0.63 & 1.34 \\
\hline & $(0.008)$ & $(0.020)$ & $(0.000)$ & $(0.665)$ & $(0.239)$ & $(0.000)$ \\
\hline \multirow[t]{2}{*}{ Woolen yarn } & -0.60 & 2.10 & -0.35 & 0.13 & 0.08 & 0.60 \\
\hline & $(0.019)$ & $(0.003)$ & $(0.353)$ & $(0.753)$ & $(0.926)$ & $(0.142)$ \\
\hline \multirow{2}{*}{$\begin{array}{l}\text { Woolens and } \\
\text { worsteds }\end{array}$} & 1.19 & 0.27 & 0.19 & 0.51 & 0.08 & 0.34 \\
\hline & $(0.006)$ & $(0.163)$ & $(0.532)$ & $(0.379)$ & $(0.885)$ & $(0.341)$ \\
\hline \multirow[t]{2}{*}{ Cotton yarn } & -0.36 & 0.11 & 1.09 & 0.85 & 0.40 & 0.99 \\
\hline & $(0.143)$ & $(0.903)$ & $(0.084)$ & $(0.197)$ & $(0.535)$ & $(0.084)$ \\
\hline \multirow[t]{2}{*}{ Cottons } & 1.11 & 0.99 & 0.97 & -0.05 & -0.94 & 1.60 \\
\hline & $(0.000)$ & $(0.000)$ & $(0.000)$ & $(0.881)$ & $(0.004)$ & $(0.000)$ \\
\hline \multirow[t]{2}{*}{ Linen yarn } & -0.56 & 0.10 & -0.45 & 0.54 & -1.30 & 1.59 \\
\hline & $(0.001)$ & $(0.759)$ & $(0.410)$ & $(0.097)$ & $(0.000)$ & $(0.006)$ \\
\hline \multirow[t]{2}{*}{ Linens } & 0.91 & -0.85 & -2.25 & -0.06 & 1.46 & 1.39 \\
\hline & $(0.000)$ & $(0.000)$ & $(0.000)$ & $(0.810)$ & $(0.028)$ & $(0.048)$ \\
\hline \multirow[t]{2}{*}{ Silk wares } & 1.58 & 0.80 & 0.95 & -0.97 & 0.81 & 1.70 \\
\hline & $(0.000)$ & $(0.008)$ & $(0.000)$ & $(0.056)$ & $(0.392)$ & $(0.002)$ \\
\hline Glass and & -1.24 & -0.73 & 0.18 & -0.84 & 0.63 & 1.70 \\
\hline \multirow{3}{*}{$\begin{array}{l}\text { glassware } \\
\text { Wines }\end{array}$} & $(0.003)$ & $(0.089)$ & $(0.731)$ & $(0.006)$ & $(0.452)$ & $(0.002)$ \\
\hline & 0.96 & 0.18 & 0.35 & 0.20 & -0.68 & 0.49 \\
\hline & $(0.058)$ & $(0.320)$ & $(0.025)$ & $(0.743)$ & $(0.377)$ & $(0.051)$ \\
\hline \multirow{3}{*}{$\begin{array}{l}\text { Spirits and } \\
\text { liqueurs }\end{array}$} & -0.63 & 1.80 & 1.59 & 0.81 & 0.94 & 4.04 \\
\hline & $(0.428)$ & $(0.000)$ & $(0.004)$ & $(0.034)$ & $(0.050)$ & $(0.000)$ \\
\hline & Simultaneou & constrained co & fficients ( $p$-valu & [Wald test $\mathrm{p}-$ & lues] & \\
\hline MFN*CountryEx & 0.045 & 0.500 & 0.700 & 0.658 & -0.530 & 1.07 \\
\hline & $(0.431)$ & $(0.000)$ & $(0.000)$ & $(0.000)$ & $(0.000)$ & $(0.000)$ \\
\hline & {$[0.000]$} & {$[0.000]$} & {$[0.000]$} & {$[0.000]$} & {$[0.000]$} & [0.000] \\
\hline System-Pseudo-R ${ }^{2}$ & & & & & & 0.91 \\
\hline Total system obser & & & & & & 18,480 \\
\hline
\end{tabular}

Source: See text

Note: See Table 5. 
Table 8

SUM COMMODITY-SPECIFIC INCREASES IN EXPORTS ATTRIBUTABLE TO MFN LIBERALIZATIONS

Export increases trade due to

MFN liberalizations (in $£$ $1,000)$

United Kingdom

France

Zollverein

Belgium

Netherlands

Austria-Hungary

Source: See text. in relation to

aggregate exports

in relation to total exports covered by

Cobden

\begin{tabular}{rrr}
1,919 & $4.1 \%$ & $6.9 \%$ \\
9,010 & $20.0 \%$ & $23.9 \%$ \\
3,946 & $11.9 \%$ & $15.5 \%$ \\
677 & $7.0 \%$ & $7.6 \%$ \\
-152 & $-3.3 \%$ & $-12.8 \%$ \\
776 & $7.6 \%$ & $7.7 \%$ \\
\hline
\end{tabular}


Table A1

[Title given in appendix title]

\begin{tabular}{|c|c|c|c|c|c|c|c|c|c|c|c|c|c|c|}
\hline & UK & $\mathrm{F}$ & $\begin{array}{c}\text { Zoll- } \\
\text { verein }\end{array}$ & BEL & NL & AUT & SUI & ITA & DK & $\begin{array}{l}\text { SWE- } \\
\text { NOR }\end{array}$ & ESP & POR & RUS & US \\
\hline UK & $\mathbf{x}$ & $\begin{array}{l}1860 \\
\text { et. al }\end{array}$ & 1865 & 1862 & & $\begin{array}{c}1865 / \\
1869\end{array}$ & & 1863 & & & & & 1859 & \\
\hline France & & $\mathbf{x}$ & $\begin{array}{l}1862 \\
\text { et. al. }\end{array}$ & $\begin{array}{l}1861 \\
\text { et. al. }\end{array}$ & 1865 & 1866 & 1864 & 1863 & & 1865 & 1865 & 1866 & 1874 & \\
\hline Zollverein & & & $\mathbf{x}$ & 1863 & & $\begin{array}{l}1865 \\
\text { et. al. } \\
(1853)\end{array}$ & 1869 & 1865 & & & 1868 & 1872 & & \\
\hline Belgium & & & & $\mathbf{x}$ & 1863 & 1867 & 1862 & 1863 & 1863 & 1863 & 1863 & 1874 & & - \\
\hline Netherlands & & & & & $\mathbf{X}$ & 1867 & 1875 & 1863 & & & 1871 & 1875 & & \\
\hline $\begin{array}{l}\text { Austria- } \\
\text { Hungary }\end{array}$ & & & & & & $\mathbf{x}$ & 1868 & 1867 & & 1873 & 1870 & 1872 & & \\
\hline Switzerland & & & & & & & $\mathbf{x}$ & 1868 & 1875 & & 1869 & 1873 & & 1855 \\
\hline Italy & & & & & & & & $\mathbf{x}$ & 1864 & 1862 & 1870 & 1872 & & \\
\hline Denmark & & & & & & & & & $\mathbf{x}$ & & 1872 & & & \\
\hline Sweden \& & & & & & & & & & & $\mathbf{x}$ & 1871 & & & \\
\hline Norway & & & & & & & & & & & & & & \\
\hline Spain & & & & & & & & & & & $\mathbf{x}$ & 1872 & & \\
\hline Portugal & & & & & & & & & & & & $\mathbf{x}$ & & \\
\hline Russia & & & & & & & & & & & & & $\mathbf{X}$ & \\
\hline $\begin{array}{l}\text { United } \\
\text { States }\end{array}$ & & & & & & & & & & & & & & $\mathbf{x}$ \\
\hline
\end{tabular}

Source: Elaborated from Parry, ed., Consolidated Treaty Series, vols. 120-150; and Glier, MeistbegünstigungsKlausel. Treaties which were not unambiguously identified as unconditional MFN treaties in the sense of the Cobden-Chevalier Treaty of 1860 are not included. The treaty between the Netherlands and Switzerland was sealed in 1875 but not ratified until the end of 1877, and has thus been excluded from Table 2 and all econometric models. Compare Accominotti and Flandreau, "Bilateral Trade Treaties," App. 2. 
Table A2

[Title given in appendix title]

\begin{tabular}{|c|c|c|c|c|c|c|c|c|}
\hline & \multicolumn{4}{|c|}{$O L S-S U R$} & \multicolumn{4}{|c|}{$P P M L-S U R$} \\
\hline & Cobden & MFN & Tailor & Obs & Cobden & MFN & Tailor & Obs \\
\hline \multirow[t]{2}{*}{ Wheat } & 0.58 & 2.01 & 0.76 & 491 & 0.14 & 1.69 & 1.28 & 880 \\
\hline & $(0.039)$ & $(0.000)$ & $(0.295)$ & & $(0.405)$ & $(0.000)$ & $(0.001)$ & \\
\hline \multirow[t]{2}{*}{ Rye } & -0.23 & 0.90 & 2.66 & 301 & 0.27 & 0.34 & 2.13 & 880 \\
\hline & $(0.311)$ & $(0.004)$ & $(0.000)$ & & $(0.284)$ & $(0.148)$ & $(0.007)$ & \\
\hline \multirow[t]{2}{*}{ Milling products } & -0.02 & 0.95 & 0.14 & 340 & 0.34 & 1.20 & -0.43 & 880 \\
\hline & $(0.961)$ & $(0.026)$ & $(0.825)$ & & $(0.230)$ & $(0.016)$ & $(0.545)$ & \\
\hline \multirow[t]{2}{*}{ Wood } & 0.23 & 0.46 & 1.23 & 469 & 0.25 & 0.28 & 1.10 & 880 \\
\hline & $(0.097)$ & $(0.006)$ & $(0.000)$ & & $(0.231)$ & $(0.161)$ & $(0.000)$ & \\
\hline \multirow{4}{*}{$\begin{array}{l}\text { Hides, skins, and } \\
\text { leather } \\
\text { Wool }\end{array}$} & 0.07 & 0.15 & -0.16 & 685 & -0.02 & 0.00 & -0.28 & 880 \\
\hline & $(0.665)$ & $(0.403)$ & $(0.428)$ & & $(0.875)$ & $(0.977)$ & $(0.056)$ & \\
\hline & 0.15 & 0.33 & 0.20 & 682 & 0.32 & 0.18 & 0.05 & 880 \\
\hline & $(0.408)$ & $(0.059)$ & $(0.464)$ & & (0.114) & $(0.426)$ & $(0.856)$ & \\
\hline \multirow[t]{2}{*}{ Silk } & 0.05 & 0.32 & 0.78 & 445 & 0.18 & 0.22 & 0.02 & 880 \\
\hline & $(0.884)$ & $(0.176)$ & $(0.063)$ & & $(0.297)$ & $(0.224)$ & $(0.948)$ & \\
\hline \multirow[t]{2}{*}{ Pig iron } & -0.16 & 0.57 & 0.39 & 311 & 0.03 & 0.42 & 0.15 & 880 \\
\hline & $(0.570)$ & $(0.029)$ & $(0.065)$ & & $(0.884)$ & $(0.014)$ & $(0.328)$ & \\
\hline \multirow[t]{2}{*}{ Bar iron and steel } & 0.04 & 0.40 & -0.10 & 412 & -0.06 & 0.61 & 0.22 & 880 \\
\hline & $(0.872)$ & $(0.089)$ & $(0.753)$ & & $(0.802)$ & $(0.016)$ & $(0.373)$ & \\
\hline \multirow[t]{2}{*}{ Ironware } & 0.30 & 0.37 & 0.67 & 376 & 0.27 & 0.29 & 0.56 & 880 \\
\hline & $(0.199)$ & $(0.143)$ & $(0.021)$ & & (0.359) & $(0.308)$ & $(0.080)$ & \\
\hline Articles of & 0.44 & 0.60 & 0.66 & 426 & 0.44 & 0.64 & 0.25 & 880 \\
\hline leather/rubber & $(0.054)$ & $(0.003)$ & $(0.014)$ & & $(0.006)$ & $(0.000)$ & $(0.165)$ & \\
\hline \multirow{2}{*}{ Woolen yarn } & 0.03 & 0.42 & 1.43 & 285 & -0.38 & -0.23 & 1.41 & 880 \\
\hline & $(0.938)$ & $(0.204)$ & $(0.000)$ & & $(0.233)$ & $(0.322)$ & $(0.000)$ & \\
\hline \multirow[t]{2}{*}{ Woolens and worsteds } & 0.33 & 0.51 & 0.39 & 421 & 0.62 & 0.61 & 0.23 & 880 \\
\hline & $(0.187)$ & $(0.018)$ & $(0.126)$ & & $(0.000)$ & $(0.001)$ & $(0.372)$ & \\
\hline \multirow[t]{2}{*}{ Cotton yarn } & -0.19 & 0.35 & 0.03 & 306 & -0.39 & -0.15 & 0.21 & 880 \\
\hline & $(0.467)$ & $(0.176)$ & $(0.897)$ & & $(0.056)$ & $(0.591)$ & $(0.591)$ & \\
\hline \multirow[t]{2}{*}{ Cottons } & -0.18 & 0.41 & 0.57 & 390 & 0.13 & 1.07 & 0.82 & 880 \\
\hline & $(0.390)$ & $(0.064)$ & $(0.010)$ & & $(0.535)$ & $(0.000)$ & $(0.000)$ & \\
\hline \multirow[t]{2}{*}{ Linen yarn } & 0.78 & 0.53 & 0.91 & 333 & 0.50 & 0.56 & 1.05 & 880 \\
\hline & $(0.024)$ & $(0.212)$ & $(0.004)$ & & $(0.067)$ & $(0.174)$ & $(0.005)$ & \\
\hline \multirow[t]{2}{*}{ Linens } & 0.78 & 0.44 & -0.19 & 355 & 0.58 & 0.77 & 0.08 & 880 \\
\hline & $(0.002)$ & $(0.134)$ & $(0.587)$ & & (0.007) & (0.015) & $(0.801)$ & \\
\hline \multirow[t]{2}{*}{ Silk wares } & 0.13 & 0.47 & 0.57 & 467 & 0.17 & 0.54 & 0.34 & 880 \\
\hline & $(0.665)$ & $(0.057)$ & $(0.110)$ & & $(0.254)$ & $(0.008)$ & $(0.281)$ & \\
\hline \multirow[t]{2}{*}{ Glass and glassware } & 0.11 & -0.21 & 0.47 & 367 & -0.24 & -0.38 & 0.15 & 880 \\
\hline & $(0.586)$ & $(0.434)$ & $(0.191)$ & & $(0.281)$ & $(0.172)$ & $(0.362)$ & \\
\hline \multirow[t]{2}{*}{ Wines } & 0.03 & 0.03 & -0.06 & 448 & -0.13 & -0.07 & 0.000 & 880 \\
\hline & $(0.870)$ & $(0.893)$ & $(0.799)$ & & $(0.437)$ & $(0.635)$ & $(0.989)$ & \\
\hline \multirow[t]{2}{*}{ Spirits and liqueurs } & 0.84 & 0.68 & -0.09 & 323 & 1.69 & 1.64 & 1.14 & 880 \\
\hline & $(0.000)$ & $(0.009)$ & $(0.838)$ & & $(0.005)$ & $(0.000)$ & $(0.000)$ & \\
\hline System-(Pseudo-)R² & 0.64 & 0.65 & 0.65 & & 0.90 & 0.90 & 0.90 & \\
\hline System Adj.-R ${ }^{2}$ & 0.58 & 0.58 & 0.58 & & - & - & - & \\
\hline System Observations & 8,633 & 8,633 & 8,633 & & 18,480 & 1,840 & 1,840 & \\
\hline
\end{tabular}

Source: See text

Note: See Table 5. 
Table A3

[Title given in appendix title]

\begin{tabular}{|c|c|c|c|c|c|c|}
\hline \multicolumn{7}{|c|}{ Simultaneously constrained coefficients (p-values) [Wald test p-values] } \\
\hline \multirow{2}{*}{$\begin{array}{l}\text { Model } \\
\text { Treaty dummy }\end{array}$} & \multicolumn{3}{|c|}{ OLS-SUR } & \multicolumn{3}{|c|}{$P P M L-S U R$} \\
\hline & Cobden & MFN & Tailor & Cobden & MFN & Tailor \\
\hline \multirow[t]{3}{*}{$\ln \left(Y_{i}\right)$} & 0.68 & 0.68 & 0.59 & 0.42 & 0.37 & 0.25 \\
\hline & (0.000) & (0.000) & (0.000) & $(0.000)$ & (0.000) & $(0.000)$ \\
\hline & [0.000] & {$[0.000]$} & {$[0.000]$} & [0.000] & {$[0.000]$} & {$[0.000]$} \\
\hline \multirow[t]{3}{*}{$\ln \left(D_{\mathrm{ij}}\right)$} & -0.59 & -0.53 & -0.45 & -0.62 & -0.64 & -0.55 \\
\hline & $(0.000)$ & $(0.000)$ & $(0.000)$ & $(0.000)$ & $(0.000)$ & $(0.000)$ \\
\hline & [0.140] & [0.081] & [0.246] & [0.000] & {$[0.000]$} & {$[0.000]$} \\
\hline \multirow[t]{3}{*}{ Border } & 0.83 & 0.89 & 0.90 & 0.73 & 0.82 & 0.64 \\
\hline & $(0.000)$ & $(0.000)$ & $(0.000)$ & $(0.000)$ & $(0.000)$ & $(0.000)$ \\
\hline & [0.000] & {$[0.000]$} & [0.000] & [0.000] & {$[0.000]$} & [0.000] \\
\hline \multirow[t]{3}{*}{ Language } & 0.72 & 0.67 & 0.66 & 0.70 & 0.69 & 0.74 \\
\hline & $(0.000)$ & $(0.000)$ & $(0.000)$ & $(0.000)$ & $(0.000)$ & $(0.000)$ \\
\hline & {$[0.000]$} & {$[0.000]$} & {$[0.000]$} & [0.000] & {$[0.000]$} & {$[0.000]$} \\
\hline \multirow[t]{3}{*}{ European War } & -0.09 & -0.08 & -0.06 & -0.13 & -0.17 & -0.13 \\
\hline & $(0.030)$ & $(0.043)$ & $(0.116)$ & $(0.000)$ & $(0.000)$ & $(0.000)$ \\
\hline & [0.112] & {$[0.077]$} & [0.124] & [0.000] & {$[0.000]$} & {$[0.000]$} \\
\hline \multirow[t]{3}{*}{ Civil War } & 0.03 & 0.00 & 0.07 & -0.21 & -0.18 & -0.19 \\
\hline & $(0.489)$ & $(0.924)$ & $(0.155)$ & $(0.000)$ & $(0.000)$ & $(0.000)$ \\
\hline & [0.000] & {$[0.000]$} & {$[0.000]$} & [0.000] & {$[0.000]$} & {$[0.000]$} \\
\hline \multirow[t]{3}{*}{ Cobden/MFN/Tailor } & 0.20 & 0.38 & 0.46 & 0.13 & 0.23 & 0.21 \\
\hline & $(0.000)$ & $(0.000)$ & $(0.000)$ & $(0.000)$ & $(0.000)$ & $(0.000)$ \\
\hline & {$[0.020]$} & [0.012] & {$[0.000]$} & {$[0.000]$} & {$[0.000]$} & {$[0.000]$} \\
\hline
\end{tabular}

Source: See text

Note: See Table 6. 
Figure 1

EVOLUTION OF TREATY AND COMMODITY-GROUP SPECIFIC LIBERALIZATION

FREQUENCIES AS CODED IN COBDEN, MFN, AND TAILOR, 1857-1861,

IN PERCENT OF ALL POSSIBLE COUNTRY-PAIRS

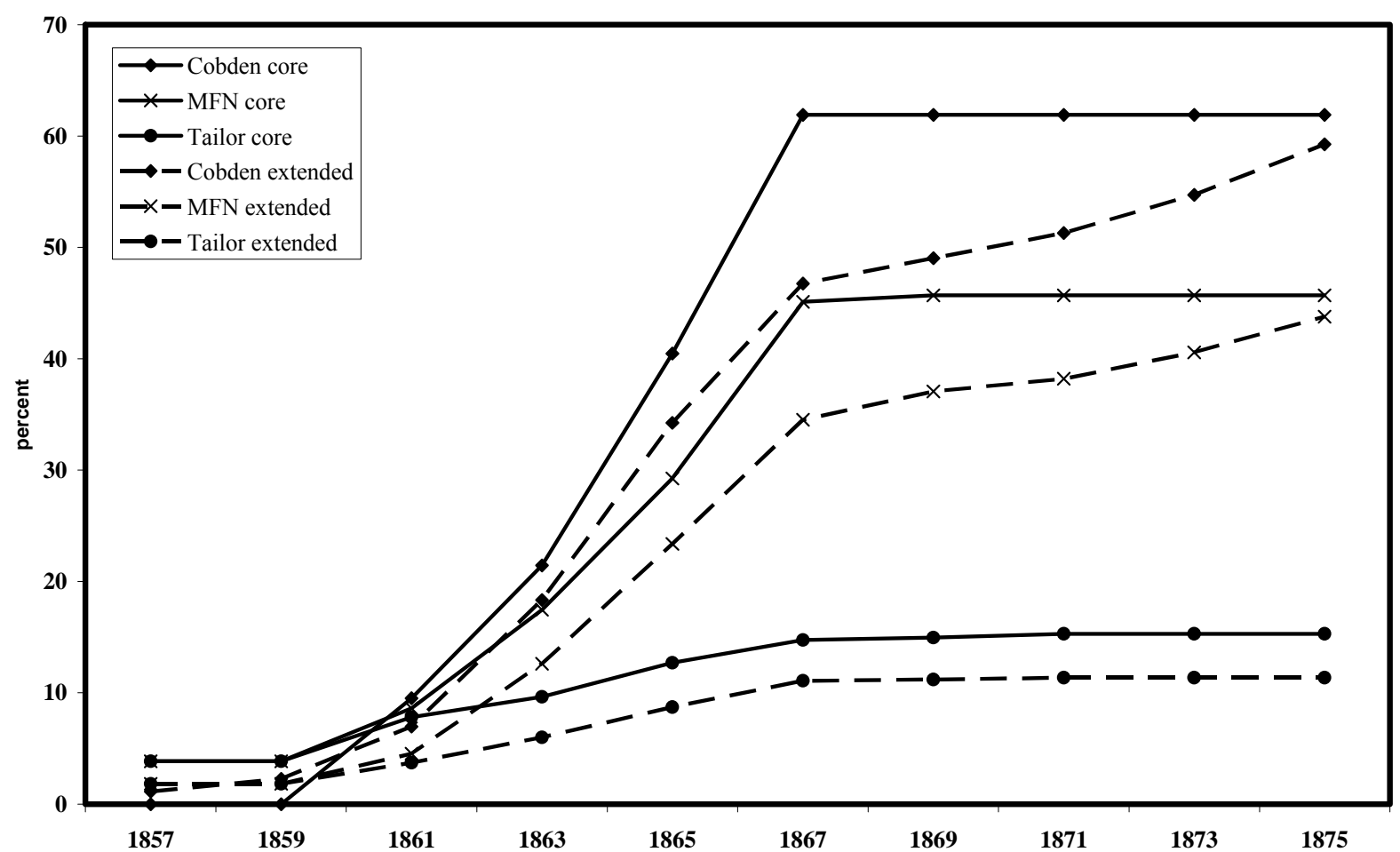

Source: See Table 2.

Note: Total commodity-group country-pairs for the core sample (continuous lines): 882 (21*42), for the extended sample (dashed lines): $1848(21 * 88)$. Commodity-specific preferences of the February Treaty between Austria-Hungary and the Zollverein (1853-June 1865) have been coded in Tailor and MFN, but the treaty was not counted in Cobden, as it was not an unconditional MFN treaty. 
Figure 2

SUM OF ADDITIONAL TRADE ATTRIBUTABLE TO SIGNIFICANT COMMODITYSPECIFIC EFFECTS IN ABSOLUTE VALUE AND IN PERCENT OF AGGREGATE

TRADE COVERED BY COBDEN TREATIES IN EACH YEAR

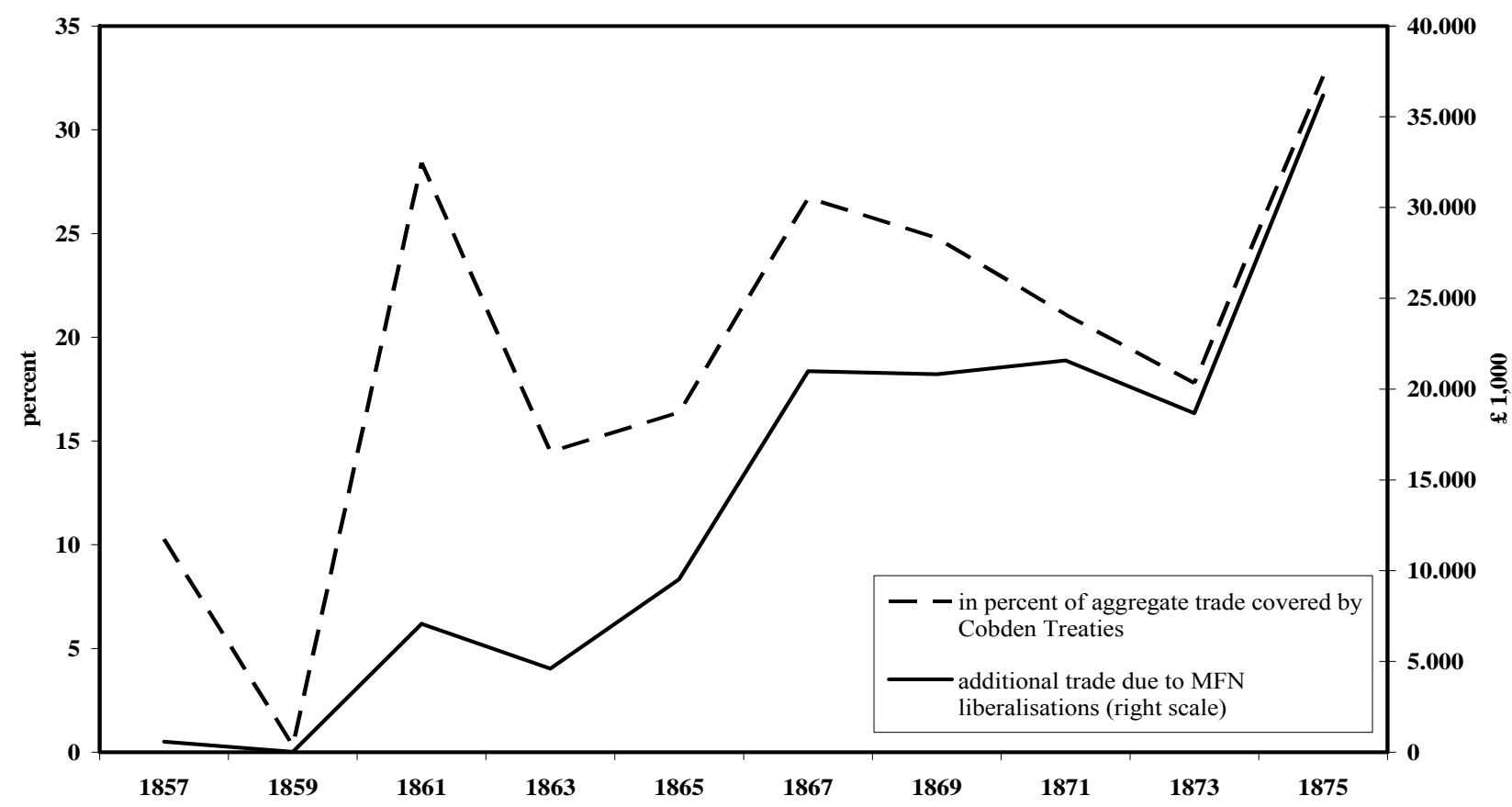

Source: See text 